\title{
ANALIZA POJEDINIH STATISTIČKIH POKAZATELJA UČINKOVITOSTI HRVATSKOG GRAĐANSKOG PRAVOSUĐA
}

Marko Mećar, mag. iur.*

UDK: $347.97 / .99: 311.21(497.5)$

DOI: $10.3935 /$ zpfz.71.34.08

Pregledni znanstveni rad

Primljeno: kolovoz 2021.

Učinkovitost građanskog pravosuđa pridonosi zaštiti prava i interesa koje osobe mogu ostvariti u određenoj državi. Dodatno, niz stručnih studija govori u prilog tome da učinkovito pravosuđe ima pozitivne učinke na gospodarsku aktivnost i na veća izravna strana ulaganja u gospodarstvo države, a time i na životni standard građana u toj državi. S obzirom na važnost navedene teme, u ovom radu analizirat će se pojedini statistički pokazatelji učinkovitosti hrvatskog građanskog pravosuđa u cjelini te zatim učinkovitost pojedinih dijelova hrvatskog građanskog pravosuđa u pogledu kojih dostupni podaci pokazuju da imaju smanjenu učinkovitost. Navedena analiza važna je i zato što predstavlja doprinos identificiranju uzroka smanjene učinkovitosti pojedinih dijelova pravosuđa, što je preduvjet da bi se moglo ponuditi odgovarajuće rješenje odnosno mjere za poboljšanje učinkovitosti pravosuđa.

Kliučne riječi: pravosuđe, Republika Hrvatska, analiza učinkovitosti, CEPEJ, EU

Marko Mećar, mag. iur., LL. M., odvjetnik, odvjetničko društvo Laktić \& partneri d.o.o., Selska cesta 90 a, 10000 Zagreb; marko.mecar@laktic.hr;

ORCID ID: orcid.org/0000-0003-2456-0865;

Svi pogledi i stavovi izneseni u ovom radu su osobni stavovi autora, i ne odražavaju službeni stav odvjetničkog ureda. 


\section{UVOD}

Učinkovitost pravosuđa ima dalekosežne učinke. ${ }^{1}$ Osim što pridonosi zaštiti prava i interesa koje osobe mogu ostvariti u određenoj državi, postoji niz stručnih studija koje govore u prilog tome da učinkovito pravosuđe ima pozitivne učinke na višu gospodarsku aktivnost i na veća izravna strana ulaganja u gospodarstvo države, a time i na viši životni standard građana u njoj. ${ }^{2}$ Tako, primjerice, smanjenje trajanja postupka pred sudom mjereno statističkim pokazateljem disposition time (dalje u tekstu: vrijeme rješavanja ili VR) ${ }^{3}$ za samo $1 \%$ može povećati rast novostvorene dodane vrijednosti, rast broja pravnih osoba i ekonomske aktivnosti u državi. ${ }^{4}$

To je i očekivano jer u zemlji u kojoj vlada pravna sigurnost i gdje sudovi postupaju na učinkovit način, gospodarstvo ima potrebne preduvjete za ostvarenje punog potencijala rasta, a strani investitori zbog pravne su sigurnosti spremni uložiti kapital jer znaju da njihovo ulaganje štiti predvidivi pravni okvir i pravna sigurnost. S druge strane, u zemlji u kojoj je pravosuđe neučinkovito vođenje parničnog postupka za poduzetnika znači višegodišnje odlaske na sud uz visoke troškove vođenja parničnog postupka te visoke iznose kamata na

1 Pojam pravosuđa koji se analizira u ovom radu odnosi se samo na građansko pravosuđe te su radi važnosti i utjecaja na prava građana i gospodarstvo u cjelini također u podatke uključeni i podaci o upravnim sudovima. Kazneni i prekršajni dio pravosuđa nije dio analize ovog članka. Dodatno, analizira se pravosuđe u užem smislu, dakle rad sudova, dok se ne analizira učinkovitost ostalih aktera koji se smatraju dijelom pravosuđa u širem smislu (npr. javni bilježnici, državni odvjetnici, odvjetnici i sl.).

2 Vidi Međunarodni monetarni fond (MMF), Regional Economic Outlook, Europe: Europe Hitting its Stride, 11/2017, MMF, Washington, 2017., str. 40 i 70; Bove, V.; Elia, L., The Judicial System and Economic Development Across EU Member States, JRC Technical Report, Publications Office of the EU, Luxembourg, 2017., str. 4 - 5; Bülent, D., Effect of Judicial Independence to FDI into Eastern Europe and South Asia, Munich Personal RePec Archive, München, 2012., str. 3 - 7; Masuch, K.; Anderton, R.; Setzer, R.; Benalal, N., Structural Policies in the Euro Area, ECB Occasional Paper Series, No. 210, Frankfurt na Majni, 2018., str. 14 - 25 i 66 - 68.

3 Statistički pokazatelj VR jedan je od statističkih pokazatelja koji se često koriste u stručnoj literaturi za procjenu je li pojedino pravosuđe učinkovito. Vidi Europska komisija, The 2020 EU Justice Scoreboard, Bruxelles, 2020., str. 8 - 18; CEPEJ, European judicial systems, Efficiency and quality of justice, CEPEJ studija br. 26, Vijeće Europe, Strasbourg, 2018., str. 5 - 10, $239-272$.

4 MMF, op. cit. u bilj. 3, str. 40 i 70; Bove et al., op. cit. u bilj. 2, str. 4 - 5; Bülent, op. cit. u bilj. 2, str. 3 - 7; Masuch et al., op. cit. u bilj. 2, str. $14-25$ i $66-68$. 
glavnicu potraživanja u slučaju gubitka sudskog spora. ${ }^{5}$ Gledajući iz perspektive pojedinačnog poduzetnika, neučinkovito pravosuđe rezultira time da u svakoj transakciji u koju poduzetnik ulazi pravni rizik koji proizlazi iz potencijalnog spora vezano uz transakciju raste proporcionalno s neučinkovitošću pravosuđa što je pravosuđe neučinkovitije, to je pravni rizik koji proizlazi iz potencijalnog sudskog spora proporcionalno veći. Povećanjem učinkovitosti pravosuđa dolazi do upravo suprotnog efekta. Smanjenjem navedenog pravnog rizika transakcije koji proizlazi iz potencijalno dugotrajnog i skupog sudskog spora dolazi do pozitivnog efekta na ponašanje aktera u gospodarstvu - poduzetnici su spremniji ući u transakciju i preuzeti poduzetnički rizik, kreditori su spremniji davati kredite, potrošači su spremniji više trošiti, a sve to jer znaju da ako njihova prava budu povrijeđena, mogu ostvariti njihovu zaštitu na učinkovit način pred sudom. ${ }^{6}$

Dodatno, u situaciji u kojoj se znatan broj kritika u javnosti u vezi s pravosuđem svodi na prigovor predugačkih i neučinkovitih postupaka te velik broj neriješenih predmeta ${ }^{7}$, proizlazi da bi prioritet $\mathrm{u}$ reformi pravosuđa trebao biti usmjeren na sposobnost sudova da riješe predmete koji se nalaze pred njima, odnosno da se poboljša učinkovitost pravosuđa. Prema tome, pitanje učinkovitosti pravosuđa nije samo pitanje statistike ili broja riješenih predmeta. Učinkovitost pravosuđa ima direktan utjecaj na gospodarski rast države te, u konačnici, na živote građana koji u njoj žive.

Iako je u medijima u Hrvatskoj postalo uobičajeno iznositi ocjene da hrvatsko pravosuđe ne funkcionira na zadovoljavajuće učinkovit način, takve ocjene po našem mišljenju ne pomažu u preciznom identificiranju i rješavanju uzroka problema neučinkovitosti pravosuđa. ${ }^{8}$ Iznošenje paušalnih ocjena o tome da pra-

\section{Ibid.}

6 Ibid.

7 Vidi primjerice novinski članak: Stotine tisuća neriješenih predmeta na hrvatskim sudovima, dostupno na: https://vijesti.hrt.hr/hrvatska/stotine-tisuca-nerijesenih-predmeta-na-hrvatskim-sudovima-2907740 (1.11.2021.) i članak: Sudovi u prošloj godini nagomilali 30.000 neriješenih predmeta više, dostupno na: https://www.tportal.hr/vijesti/clanak/sudovi-u-prosloj-godini-nagomilali-30-000-nerijesenih-predmeta-vise-20210902 (11.11.2021.).

8 Vidi, primjerice, novinske članke:

- Neučinkovitost hrvatskog pravosuđa vrhunac je doživjela na primjeru Bandića, dostupno na: https://hr.nlinfo.com/vijesti/neucinkovitost-hrvatskog-pravosuda-vrhunac-jedozivjela-na-primjeru-bandica/ (22. listopada 2021.) i

- Sukob Plenkovića i Milanovića samo je simptom bolesnoga pravosuda: Tko imenuje vrhovne suce u drugim zemljama EU-a?, dostupno na: https://www.tportal.hr/komentatori/clanak/ sukob-plenkovica-i-milanovica-samo-je-simptom-bolesnog-pravosuda-tko-imenuje-vrhovne-suce-u-drugim-zemljama-eu-foto-20210323 (22. listopada 2021.). 
vosuđe u cijelosti funkcionira loše, ma koliko bilo uobičajeno i često korišteno u javnom prostoru, ne doprinosi pronalasku kvalitetnih rješenja koja će se usmjeriti na stvarne uzroke tog problema. Kad su suočeni s kritikama javnosti u vezi s funkcioniranjem pravosuđa, razni dionici poput političara ili istaknutih sudaca u svojim se nastupima redovito pozivaju na pozitivne pomake i rezultate $u$ radu pravosuđa. ${ }^{9}$ Nakon toga daljnja rasprava i detaljna analiza stanja pravosuđa $u$ medijima prestane jer nisu interesantni široj publici. Prema tome, postavlja se vrlo jednostavno pitanje: tko je u pravu - javnost koja uporno kritizira rad pravosuđa ili dionici koji se u obrani pravosuđa pozivaju na postignute pozitivne pomake u radu pravosuđa.

\section{METODOLOGIJA}

Cilj ovoga rada je na temelju pojedinih javno objavljenih statističkih podataka identificirati u kojem dijelu pravosuđe funkcionira nedovoljno učinkovito, a u kojem dijelu funkcionira eventualno dovoljno učinkovito. Na taj bi se način moglo preciznije odrediti na koji dio pravosuđa treba fokusirati mjere da bi se učinkovitost pravosuđa poboljšala. Međutim, ambicija koja se nastojala postići ovim radom ima nekoliko ograničenja. Prvo, sudovi ne funkcioniraju u vakuumu te postoje vanjski čimbenici koji su izvan izravne kontrole sudova, no umanjuju učinkovitost sudova u rješavanju predmeta, kao što su pitanje učinkovitosti dostave $^{10}$, nedovoljna razina digitalizacije pravosuđa ${ }^{11}$, općenito neadekvatna

9 Vidi, primjerice, sljedeće izjave bivšeg ministra nadležnog za pravosuđe Bošnjakovića:

- Iz godine u godinu imamo bolje rezultate, sve više predmeta rješavamo, postupke smo ubrzali, dostupno na: https://www.jutarnji.hr/vijesti/hrvatska/kako-vratiti-povjerenje-u-pravosude-bosnjakovic-imamo-bolje-rezultate-postupke-smo-ubrzali-alisvjesni-smo-da-to-jos-uvijek-nije-zadovoljavajuce-7944412 (20. kolovoza 2020.) i

- Broj neriješenih predmeta u hrvatskom pravosudu pao je s 1,6 milijuna, koliko ih je bilo prije sedam-osam godina, na 350 tisuća krajem prošle godine, dostupno na: https:// vlada.gov.hr/vijesti/bosnjakovic-pad-broja-nerijesenih-predmeta-s-1-6-milijuna-na-350-tisuca/28291 (13. listopada 2021.).

10 Uzelac, A., Dostava sudskih pismena, hrvatska iskustva nakon novele Zakona o parničnom postupku iz 2008. i pouke koje se iz njih mogu izvući, dostupno na: https://pravosudje.ba/ vstv/faces/docservlet?p_id_doc=4206, (18. kolovoza 21.); Uzelac, A.; Bratković, M.; Mileković, E., Dostava preko sudske oglasne ploče: mogućnosti i ograničenja, u: Šago, D. et al. (ur.), Zbornik radova s IV. međunarodnog savjetovanja Aktualnosti građanskog procesnog prava - nacionalna i usporedna pravnoteorijska i praktična dostignuća, Pravni fakultet Sveučilišta u Splitu, Split, 2018., str. 455 - 468.

11 Uzelac, A., The Rule of Law and the Croatian Judicial System: Court Delays as a Barrier on the Road to European Accession, u: Frosini, J.; Lupoi, M. A.; Marchesiello, M. (ur.), 
fizička infrastruktura sudova ${ }^{12}$, prečeste izmjene $\operatorname{propisa}^{13}$ i dr. Navedeni vanjski čimbenici ne analiziraju se u ovom radu, no oni su prepreka učinkovitijem radu pravosuđa. Drugo, postoji ozbiljan nedostatak javno dostupnih podataka koji bi bili temelj za kvalitetnu i sveobuhvatnu analizu učinkovitosti pravosuđa, što je iznenađujuće s obzirom na važnost tih podataka. Upravo je nedostatak kvalitetnih i detaljnih podataka o učinkovitim i neučinkovitim aspektima pravosuđa jedan od čimbenika koji utječu na nemogućnost provođenja analize koja bi rezultirala detaljnijim pregledom onih dijelova pravosuđa koji su neučinkoviti i koje bi eventualno trebalo reformirati. Neki od uobičajenih pokazatelja koji se koriste u literaturi koja se bavi ocjenom učinkovitosti pravosuđa jesu:

1. stvarno trajanje postupka pred sudom

2. statistički pokazatelji VR-a i stopa ažurnosti (dalje u tekstu: SA)

3. broj neriješenih predmeta

4. broj sudaca u pravosuđu

5. broj primljenih predmeta po sucu

6. broj riješenih predmeta po sucu i

7. ukupnost troškova koji se izdvajaju za pravosuđe. ${ }^{14}$

A European Space of Justice, Longo, Ravenna, 2006., str. 87 - 108 i 124 - 125; World Bank, National Development Strategy Croatia 2030 Policy Note: Justice Sector, World Bank, Washington, DC, 2019., str. 17 - 18, 23 - 25, 36 - 38 i 42 - 48.

Ibid.

13 World Bank, op. cit. u bilj. 11, str. 6, 10 - 11 .

14 Navedeni se pokazatelji navode u sljedećoj literaturi: Europska komisija, op. cit. u bilj. 3, str. 8 - 18; CEPEJ, op. cit. u bilj. 3, str. 5 - 10, 239 - 272; European Network of Councils for the Judiciary, Judicial Reform in Europe, Report 2011-2012, ENCJ, Dublin, str. 5 - 15; Dimitrova-Grajzl, V.; Grajzl, P.; Sustersic, J.; Zajc, K., Court Output, Judicial Staffing, and the Demand for Court Services: Evidence from Slovenian Courts of First Instance, International Review of Law and Economics, vol. 32, br. 1, 2012., str. 2 - 17; Organisation for Economic Cooperation and Development (OECD), Judicial performance and its determinants: a cross-country perspective, A Going for Growth Report, Policy Paper No. 5, OECD, Pariz, 2013., str. 20; Langbroek, P.; Kleiman, M.; Lee, C. G.; Schauffler, R.; Ostrom, B., Backlog Reduction Programs and Weighted Caseload Methods for South East Europe, Two Comparative Inquiries, Regional Cooperation Council, FINAL REPORT, 2016., str. 10 - 37, dostupno na: https://www.rcc.int/pubs/32/ backlog-reduction-programmes-and-weighted-caseload-methods-for-south-east-europe-two-comparative-inquiries (24. kolovoza 2021.); Uzelac, A., Features and Shortcomings of Appellate Review in Civil and Administrative Cases in Croatia, u: Uzelac, A.; van Rhee, R. (ur.), Nobody's Perfect, Comparative Essays on Appeals and other Means of Recourse against Judicial Decisions in Civil Matters, Intersentia, Cambridge - Antwerp - Portland, 2014., str. 229 - 247; Uzelac, A., Ustavno pravo na žalbu u građanskim 
Detaljna analiza učinkovitosti hrvatskog pravosuđa po svim navedenim kriterijima prelazila bi okvire ovog rada. Dodatno, statistički podaci o nekima od navedenih pokazatelja nisu javno dostupni kao što je, primjerice, stvarno trajanje postupka pred sudom. ${ }^{15}$

S obzirom na navedeno, u ovom radu fokusirat ćemo se na: (a) statističke pokazatelje VR-a i SA-a kojima se koristi Komisija Vijeća Europe za ocjenu učinkovitosti pravosuđa (dalje u tekstu: CEPEJ) i koji su korisni kada se želi usporediti stanje u domaćem pravosuđu s pravosuđem drugih država te (b) statističke pokazatelje iz izvještaja ministarstva nadležnog za pravosuđe o broju neriješenih predmeta, brojnosti sudaca te broju primljenih i riješenih predmeta po sucu, koji upućuju na opterećenost sudaca u pravosuđu. ${ }^{16}$

Navedeni podaci VR-a i SA-a kojima se koristi CEPEJ interesantni su zbog dvaju razloga, no u njihovoj upotrebi potreban je oprez. Prvi razlog interesantnosti CEPEJ-ovih podataka jest to što se oni tiču građanskog dijela pravosuđa, što upućuje na zaključak da domaće institucije ipak raspolažu vrijednim podacima koji se tiču učinkovitosti građanskog dijela pravosuđa, samo što ih nažalost ne objavljuju u potpunosti. Takva praksa domaćih tijela nažalost onemogućuje sveobuhvatnu analizu uzroka smanjene učinkovitosti građanskog dijela pravosuđa. Drugi razlog je to što CEPEJ-ovi podaci omogućuju usporedbu pravosuđa različitih zemalja unutar EU-a, a iz te se usporedbe mogu pokušati izvući određeni zaključci i u pogledu domaćeg pravosuđa. Međutim, u pogledu usporedbe hrvatskog pravosuđa s drugim pravosuđima unutar EU na temelju CEPEJ-ovih podataka potrebno je napomenuti da postoje određena ograničenja s obzirom na statističke nedosljednosti u pogledu računanja rezultata učinkovitosti pravosuđa. Razlog tome jest to što su tijela nacionalnih država nadležna za klasifikaciju vlastitih postupaka pred sudovima i za dostavu navedenih podataka CEPEJ-u, pa je moguće da se u različitim državama suštinski iste vrste postupaka klasificiraju unutar različitih kategorija, ovisno o primje-

stvarima: jamstvo ispravnog pravosuđenja ili relikt prošlosti, u: Uzelac, A.; Garašić, J.; Maganić, A. (ur.), Djelotvorna pravna zaštita u pravičnom postupku. Izazovi pravosudnih transformacija na jugu Europe, Liber Amicorum Mihajlo Dika, Pravni fakultet Sveučilišta u Zagrebu, Zagreb, 2013., str. 236 - 241.

15 Umjesto podatka o stvarnom trajanju postupka pred sudom ministarstvo nadležno za pravosuđe koristi se statističkim pokazateljem za koji upotrebljava neujednačeno nazivlje poput "vrijeme rješavanja predmeta", "vrijeme potrebno za rješavanje predmeta", "vrijeme trajanja postupka", "disposition time" i "DT", a ti različiti nazivi označavaju statistički pokazatelj VR. Vidi Statistički pregled Ministarstva pravosuđa za 2020. godinu, str. 9, 10, 18, 26, 32, 34, 39, 51, 120 i dr.

16 Vidi Europska komisija, op. cit. u bilj. 3, str. 6 i 11. 
njivim nacionalnim propisima. ${ }^{17}$ Primjerice, postupci oduzimanja poslovne sposobnosti u Francuskoj se smatraju građanskim parničnim predmetima, dok se u Italiji (kao i u Hrvatskoj) smatraju građanskim izvanparničnim predmetima. ${ }^{18}$ Isto tako, moguće je da je za rješavanje suštinski istih predmeta u jednoj državi nadležan sud, dok je u drugoj državi nadležno upravno tijelo. ${ }^{19}$ Osim navedenoga, moguće je da se u pojedinoj državi mijenja klasifikacija iste vrste postupka tijekom vremena. Tako je u Rumunjskoj ovršni postupak u nekoliko navrata mijenjao klasifikaciju iz sudskog postupka u izvansudski postupak te natrag u sudski postupak. ${ }^{20}$ Takve okolnosti čine ograničenom mogućnost korištenja CEPEJ-ovih podataka radi usporedbe učinkovitosti između pravosuđa različitih država i analizu kretanja učinkovitosti pravosuđa iste države tijekom određenog razdoblja kada je tijekom promatranog razdoblja došlo do promjene u kategorizaciji pojedine vrste postupka.

Unatoč tome, mislimo da je prikaz CEPEJ-ovih statističkih podataka (uz sva njihova ograničenja) koristan zbog više razloga. Prvo, jer se navedeni CEPEJ-ovi podaci upotrebljavaju za procjenu učinkovitosti nacionalnih pravosuđa za potrebe Europskog semestra u okviru kojeg se provode strukturne reforme u državama članicama EU-a. ${ }^{21}$ Također, riječ je o podacima koji su često polazišna osnova za raspravu u javnim medijima o trenutačnom stanju domaćeg pravosuđa. ${ }^{22}$ U tom smislu korisno je istražiti što govore podaci koji se koriste kao podloga za buduće reforme domaćeg pravosuđa u okviru Europskog semestra i koji se citiraju u javnim medijima. Drugo, pojedine nedosljednosti u CEPEJ-ovim podacima koje se tiču naknadnih promjena i usklađivanja navedenih podataka vrlo su ograničenog opsega i one utječu na manje od $+/-1 \%$ krajnjeg rezultata. ${ }^{23}$ Dakle, navedene nedosljednosti, iako objektivno postoje, nisu većeg opsega te je u tom smislu moguće tvrditi da ipak CEPEJ-ovi podaci mogu u tom dijelu dati

17 Tako i Ontanu, E. A.; Velicogna, M., The challenge of comparing EU Member States Judicial Data Court Output, Oñati Socio-Legal Series, vol. 11, br. 2, 2021., str. $464-475$. Vidi i Uzelac, A., Efficiency of European Justice Systems. The strength and weaknesses of the CEPEJ evaluations, International Journal of Procedural Law, vol. 1, br. 1, 2011., str. $138-142$.

18 Ibid.

19 Ibid.

20 Ibid.

21 Europska komisija, op. cit. u bilj. 3, str. 2 - 3 .

22 Vidi npr. novinski članak $u$ kojem se navode CEPEJ-ovi podaci na poveznici: https://www.vecernji.hr/vijesti/prvi-donosimo-istinu-o-hrvatskom-pravosu-u-alarmantni-izvjestaj-vijeca-europe-1275689 (3. kolovoza 2021.)

Ontanu, op. cit. u bilj. 17, str. $466-473$. 
utemeljenu podlogu za usporedbu učinkovitosti pojedinih pravosuđa. Treće, podaci CEPEJ-a se ipak se koriste u pravnoj literaturi kao podloga za analizu učinkovitosti pravosuđa jer oni mogu upućivati na to da u pojedinom pravosuđu postoje određeni trendovi rasta odnosno pada učinkovitosti ili pak greške sistemske prirode i jer imaju indikativnu vrijednost. ${ }^{24}$ Stoga ćemo upravo u tu svrhu analizirati CEPEJ-ove podatke kako bismo utvrdili mogu li se iščitati kakvi trendovi u kretanju učinkovitosti hrvatskog pravosuđa te ćemo onda zaključak dodatno provjeriti putem podataka koje objavljuje ministarstvo nadležno za pravosuđe, i to podataka ministarstva o broju neriješenih predmeta, brojnosti sudaca te broju primljenih i riješenih predmeta po sucu za hrvatsko pravosuđe i vidjeti koji se zaključci mogu otuda izvući.

Prema tome, uz sva ograničenja koja postoje u vezi s korištenjem navedenih podataka CEPEJ-a i ministarstva nadležnog za pravosuđe, a koja će biti izražena u ovom radu, smatramo da je ipak moguće izvesti određene zaključke o (ne)učinkovitosti pojedinih dijelova pravosuđa za koje smatramo da doprinose raspravi o učinkovitosti pravosuđa. U odnosu na CEPEJ-ove podatke fokusirat ćemo se na pokazatelje VR-a i SA-a.

Disposition time ili vrijeme rješavanja (VR) ili, kako se nekad naziva u domaćoj literaturi, procijenjeno vrijeme trajanja postupk $\mathrm{a}^{25}$, predstavlja umnožak omjera neriješenih i riješenih predmeta na kraju godine te broja dana u godini. Formula za računanje pokazatelja VR-a je sljedeća: ${ }^{26}$

broj neriješenih predmeta

vrijeme rješavanja $(\mathrm{VR})=\frac{\text { na kraju godine }}{\begin{array}{l}\text { broj riješenih predmeta } \\ \text { na kraju godine }\end{array}} \times 365$

24 Uzelac, op.cit. u bilj. 17, str. 126 - 133.

25 U Izvješću predsjednika Vrhovnog suda Republike Hrvatske o stanju sudbene vlasti za 2020. godinu koristi se neujednačeno nazivlje kao što je "procijenjeno vrijeme trajanja sudskih postupaka", "očekivano vrijeme trajanja postupka", "vrijeme rješavanja predmeta", "vrijeme potrebno za rješavanje predmeta", "vrijeme trajanja postupka", "disposition time" i "DT". Vidi Izvješće predsjednika Vrhovnog suda Republike Hrvatske o stanju sudbene vlasti za 2020. godinu, str. 40, 48, 61 - 62, 90 - 92.

26 U literaturi se može naći i druga formula za izračun VR-a koja se koristi pokazateljem Case Turnover Ratio (dalje u tekstu: CTR), ali je u biti matematički ista formula kao i formula za VR navedena u ovom radu. Navedena druga formula za VR glasi: $\mathrm{VR}=365 / \mathrm{CTR}$, pri čemu je CTR $=$ broj riješenih predmeta u promatranom periodu / broj neriješenih predmeta u promatranom periodu. Vidi Grubišin, M.; Vlahek, I.; Milić, N.; Pomykalo, V.; Oreb, Z.; Minauf, M.; Jakovac, V., Vodič kroz pravosuđe, Ministarstvo pravosuđa, Zagreb, 2016., str. 98 - 100. 
Vrijednost VR-a uspoređuje broj neriješenih predmeta s riješenim predmetima na kraju razdoblja od godine dana, a rezultat se množi s 365. Time se dobiva vrijednost koja se izražava u danima, odnosno vrijednost koja govori koliko učinkovito promatrani sud ili sudovi upravljaju neriješenim predmetima u postupku unutar godine dana. Ako se kao ulazni parametri koriste podaci o određenoj vrsti predmeta pred određenim sudom (primjerice, podaci o riješenim/neriješenim parničnim postupcima pred Trgovačkim sudom u Zagrebu), ujedno se dobiva okvirna slika o tome koliko dana bi predvidivo moglo trajati rješavanje te vrste predmeta pred tim određenim sudom (procijenjeno trajanje postupka), ali je važno naglasiti da taj pokazatelj ne pokazuje koje je stvarno prosječno ili najkraće prosječno trajanje postupka. ${ }^{27}$

Clearance rate ili stopa ažurnosti (SA) ili stopa rješavanja / stopa ažurnosti suda predstavlja omjer riješenih i primljenih predmeta u promatranom periodu pomnoženo sa 100. Formula za računanje SA je sljedeća:

riješeni predmeti

stopa ažurnosti $(\mathrm{SA})(\%)=\frac{\mathrm{u} \text { promatranom periodu }}{\text { primljeni predmeti }} \times 100$

u promatranom periodu

SA od 100 \% pokazuje da sud rješava onoliko predmeta koliko je i primio (tzv. ulazni predmeti), SA viši od 100 \% pokazuje da sud rješava više predmeta nego što ih prima, što znači da se broj neriješenih predmeta iz prethodnih godina smanjuje, dok SA niži od 100 \% znači da se broj neriješenih predmeta povećava jer sud rješava manje predmeta nego što ih prima.

\section{ANALIZA POJEDINIH STATISTIČKIH POKAZATELJA UČINKOVITOSTI PRAVOSUĐA}

U nastavku slijedi analiza učinkovitosti hrvatskog pravosuđa usporedbom CEPEJ-ovih podataka o pokazateljima VR-a i SA-a za hrvatsko pravosuđe sa statističkim pokazateljima VR-a i SA-a za pravosuđa ostalih zemalja u EU-u te analiza podataka ministarstva nadležnog za pravosuđe o broju neriješenih predmeta, brojnosti sudaca te broju primljenih i riješenih predmeta po sucu za hrvatsko pravosuđe u cjelini (točka 3.1.). Zatim slijedi analiza navedenih podataka ministarstva nadležnog za pravosuđe o učinkovitosti pojedinih hrvatskih sudova (točka 3.2.).

27 Vidi https://sudovi.hr/hr/statistike/rezultati-rada-sudova (18. kolovoza 2021.). Tako i Grubišin et al., op. cit. u bilj. 26, str. 98 - 100. 


\subsection{Pojedini statistički pokazatelji učinkovitosti pravosuđa u Hrvatskoj i usporedba s pravosuđima ostalih zemalja u EU-u}

Uspoređujući CEPEJ-ove podatke za pokazatelje VR-a za sve prvostupanjske građanske i trgovačke parnične i izvanparnične predmete za razdoblje od 2012. do 2018. godine, vidljivo je da hrvatsko pravosuđe ostvaruje VR koji ga svrstava u sredinu država EU-a po rezultatu (12. mjesto od 27 država članica EU-a u pogledu navedenih postupaka, pri čemu četiri države članice EU-a nisu dostavile podatke). ${ }^{28}$ Tako za 2018. godinu medijan ${ }^{29}$ za VR iznosi između 91 dan, dok je rezultat hrvatskog pravosuđa 102 dana.

Dakle, po pitanju pokazatelja VR-a za ovako široko postavljenu grupu predmeta rezultat hrvatskog pravosuđa je 12 \% lošiji od medijana za zemlje EU-a. VR hrvatskog pravosuđa za preostale godine (2012. - 2016.) ne odstupa značajno od navedenog rezultata.

Tablica I. VR pokazatelj za prvostupanjske građanske i trgovačke parnične i izvanparnične predmete ${ }^{30}$

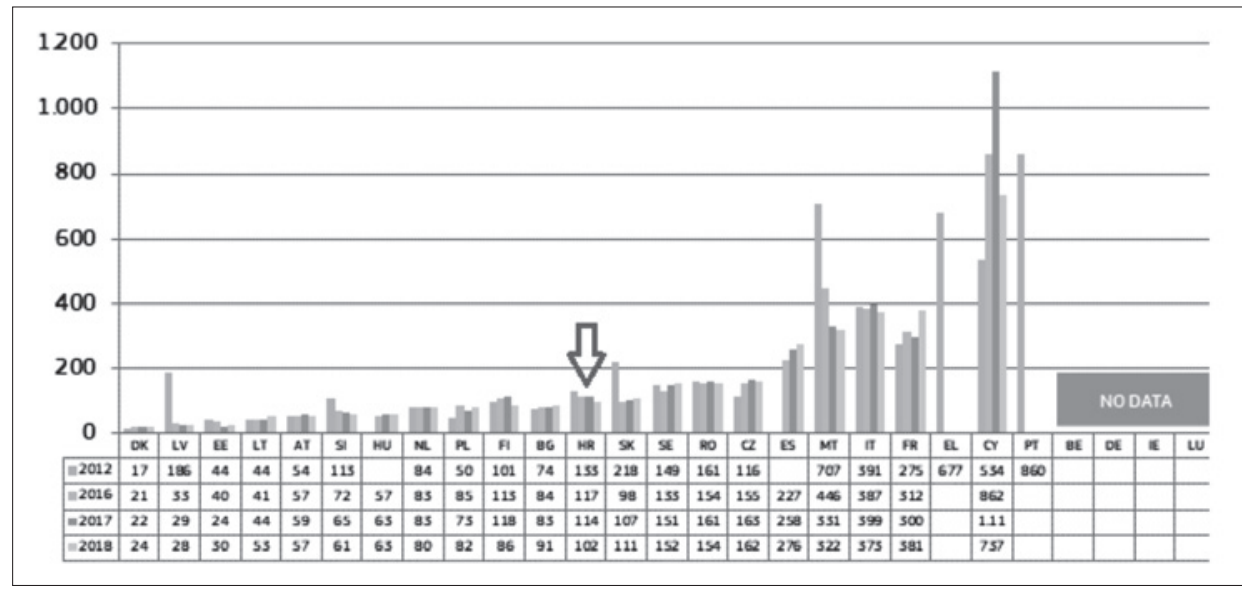

28 Europska komisija, The 2020 EU Justice Scoreboard Quantitative Data, Bruxelles, 2020., tablica 5, str. 3.

29 Za ocjenu rezultata zemalja EU-a kao mjerodavna srednja vrijednost uzet je medijan s obzirom na veliku disperziju rezultata zemalja EU-a zbog čega prosjek (aritmetička sredina) ne bi bio podoban.

30 Europska komisija, op. cit. u bilj. 28, tablica 5, str. 3. Prema metodologiji CEPEJ-a ova kategorija predmeta uključuje sve građanske i trgovačke sporove i izvanparnične slučajeve, izvanparnične zemljišnoknjižne i postupke u sudskom registru, ostale registarske predmete, ostale izvanparnične predmete, upravnopravne predmete i druge nekaznene predmete. 
Kada su u pitanju parnični predmeti, koji su vrlo često predmet kritika u javnosti glede sporosti postupanja sudova, hrvatsko pravosuđe po pokazatelju VR-a pripada manje učinkovitim pravosuđima u EU-u, odnosno 19. je od 27 članica EU-a (od čega četiri članice EU-a nisu dostavile podatke), što je vidljivo iz Tablice 2. Medijan VR vrijednosti država EU-a za 2018. godinu iznosi 213,5 dana, dok hrvatski VR iznosi 374 dana, dakle 76 \% je lošiji od medijanskog rezultata država EU-a. Proizlazi da su po pitanju pokazatelja VR-a za parnične predmete rezultati hrvatskih sudova značajno lošiji od sudova drugih zemalja EU-a.

Tablica 2. VR pokazatelj za prvostupanjske građanske i trgovačke parnične predmete ${ }^{31}$

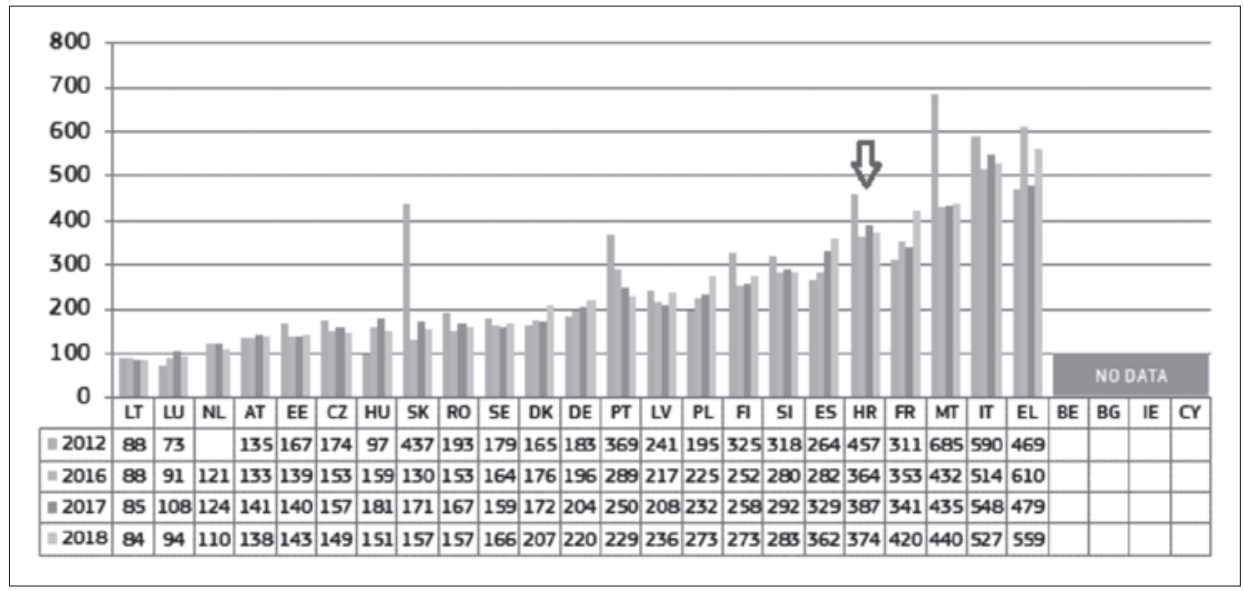

Kad je riječ o pokazatelju SA-a, hrvatsko pravosuđe stoji bolje - po tom pokazatelju Hrvatska je šesta od ukupno 27 država članica EU-a (pri čemu dvije zemlje nisu dostavile podatke). Podaci pokazuju da je u razdoblju od 2012. do 2018. godine pokazatelj SA-a hrvatskog pravosuđa bio pozitivan, odnosno viši od $100 \%$, što znači da su sudovi u promatranim postupcima (prvostupanjski građanski i trgovački parnični i izvanparnični predmeti) rješavali više predmeta nego što ih je ušlo u pravosudni sustav. Medijanski rezultat država EU-a za vrijednost SA-a za 2018. godinu iznosi 100 \%, dok je hrvatski bolji 4 \% i iznosi $104 \%$, što je vidljivo iz Tablice 3.

31 Ibid., tablica 6. Prema metodologiji CEPEJ-a ova kategorija predmeta uključuje sve građanske i trgovačke parnične postupke. 
Tablica 3. SA pokazatelj za rješavanje prvostupanjskih građanskih i trgovačkih parničnih i izvanparničnih predmeta ${ }^{32}$

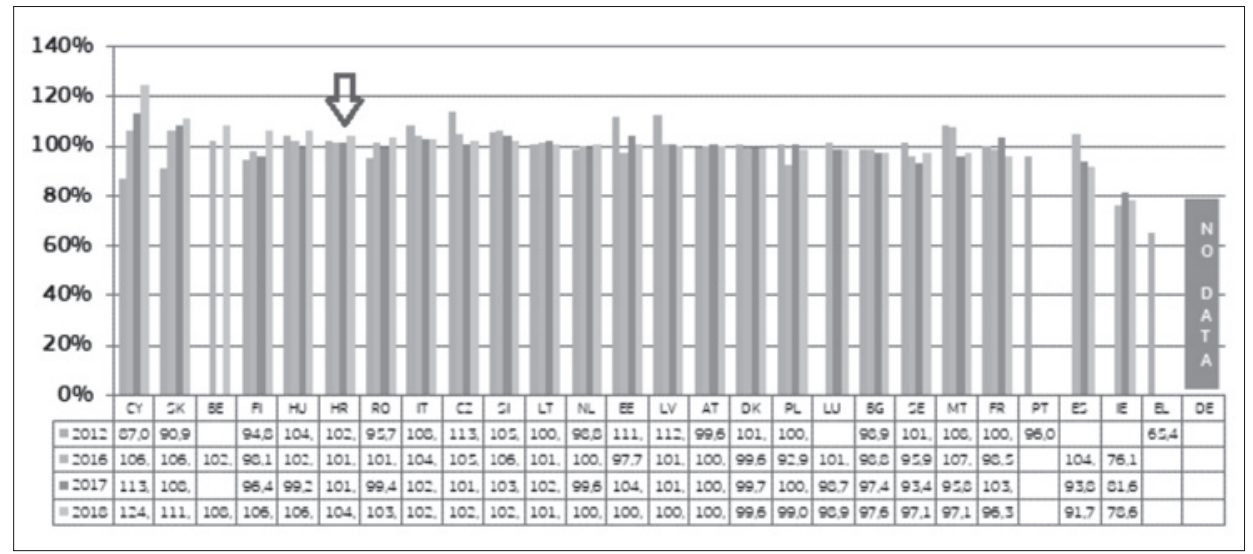

Pokazatelj SA-a iznadprosječan je i za parnične postupke, a prema njemu je hrvatsko pravosuđe na trećem mjestu, što je vidljivo iz Tablice 4. Medijanski rezultat država EU-a za 2018. godinu predstavlja 101,2 \%, dok je hrvatski rezultat solidnih $112,5 \%$.

Tablica 4. SA pokazatelj za rješavanje prvostupanjskih građanskih i trgovačkih parničnih predmeta $^{33}$

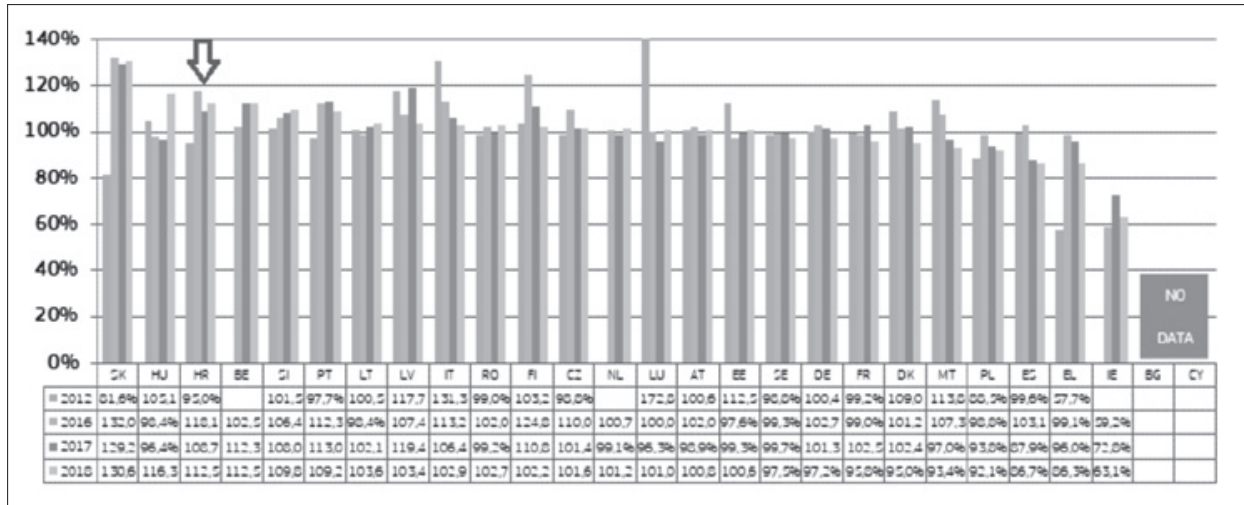

Podatke CEPEJ-a treba uzimati s oprezom zbog statističkih nedosljednosti koje postoje u navedenim podacima. Međutim, ti su podaci indikativne vrijed-

32 Ibid., tablica 10.

33 Ibid., tablica 11. 
nosti i mogu upućivati na trendove u padu ili rastu učinkovitosti, odnosno na eventualno postojanje pogrešaka koje su sistemske prirode u pogledu učinkovitosti pojedinog pravosuđa. ${ }^{34} \mathrm{U}$ tom smislu indikativno je da CEPEJ-ovi podaci upućuju na iznadprosječni SA te nešto lošiji VR (osobito za parnične postupke). Navedeni rezultati u praksi bi trebali značiti da hrvatsko pravosuđe rješava više predmeta nego što ih ulazi u sustav, pa se smanjuje broj zaostalih neriješenih predmeta, pri čemu je broj neriješenih predmeta i dalje nepovoljan (što utječe na nešto viši VR), pogotovo u pogledu parničnih postupaka.

Kako CEPEJ-ove podatke treba uzimati s oprezom zbog opisanih nedostataka, korisno je analizirati što nam govore službeni podaci ministarstva nadležnog za pravosuđe, odnosno podržavaju li navedeni zaključak koji proizlazi iz CEPEJ-ovih podataka. Iz podataka ministarstva se može zaključiti da opisani trend smanjenja neriješenih predmeta u pravosuđu uistinu postoji. Usporedbe radi:

- 2004. godine broj neriješenih predmeta bio je $1.265 .008^{35}$

- 2011. godine broj neriješenih predmeta bio je $550.358^{36}$

- 2019. godine broj neriješenih predmeta bio je $329.604^{37}$

- 2020. godine broj neriješenih predmeta bio je 317.05738,

što predstavlja pad neriješenih predmeta od respektabilnih $40 \%$ u osam godina (2011. - 2019.) i čak 75 \% u 16 godina (2004. - 2020.). O navedenom padu broja neriješenih predmeta pisalo se u nizu novinskih članaka i redovito su se na navedeni pad neriješenih predmeta pozivali razni dionici u javnim nastupima naglašavajući da je riječ o značajno pozitivnom trendu, s čime je teško ne složiti se. ${ }^{39}$ Prema tome, na prvi pogled, navedeni statistički pokazatelji VR-a i SA-a te pad broja neriješenih predmeta mogli bi govoriti u prilog zaključku

34 Uzelac, op. cit. u bilj. 16, str. 126 - 133.

35 Podatak izračunan na temelju podataka iz Statističkog pregleda Ministarstva pravosuđa za 2006., str. 15 - 16, dostupno na: https://mpu.gov.hr/pristup-informacijama-6341/strategije-6346/statisticki-pregled-o-radu-sudova/6719 (1. lipnja 2021.).

36 Podatak izračunan na temelju podataka iz Statističkog pregleda Ministarstva pravosuđa za 2012., str. 17, dostupno na: https://mpu.gov.hr/pristup-informacijama-6341/strategije-6346/statisticki-pregled-o-radu-sudova/6719 (1. lipnja 2021.).

37 Podatak izračunan na temelju podataka iz Statističkog pregleda Ministarstva pravosuđa za 2019., str. 23, dostupno na: https://mpu.gov.hr/pristup-informacijama-6341/strategije-6346/statisticki-pregled-o-radu-sudova/6719 (1. lipnja 2021.).

38 Podatak izračunan na temelju podataka iz Statističkog pregleda Ministarstva pravosuđa za 2020., str. 23, dostupno na: https://mpu.gov.hr/pristup-informacijama-6341/strategije-6346/statisticki-pregled-o-radu-sudova/6719 (1. lipnja 2021.).

39 Vidi https://www.24sata.hr/news/pad-broja-nerijesenih-predmeta-s-16-milijuna-na350-tisuca-661649_(18. kolovoza 2021.) te http://hr.nlinfo.com/Vijesti/a453984/ 
da je stanje u hrvatskom pravosuđu po učinkovitosti unutar prosjeka EU-a za sve građanske i trgovačke predmete (dakle, parnične i izvanparnične predmete) te je lošije od prosjeka EU-a za građanske i trgovačke parnične predmete, dok stanje u pogledu neriješenih predmeta, što je možda jedan od najvećih problema hrvatskog pravosuđa, napreduje vrlo dobro. Međutim, preciznija analiza drugih podataka koji upućuju na kretanje učinkovitosti hrvatskih sudova pokazuje da nema mjesta pretjeranom zadovoljstvu zbog triju razloga.

Prvi razlog jest to što navedena CEPEJ-ova statistika pokazatelja VR-a i SA-a za sve prvostupanjske građanske predmete za hrvatske sudove ne daje vjernu sliku jer su u navedenu statistiku predmeta pred sudovima uključeni izvanparnični postupci. Izvanparnični postupci specifični su jer se u pravilu rješavaju vrlo brzo te predstavljaju znatno manje opterećenje za pravosudni sustav u odnosu na, primjerice, parnične postupke, a pred hrvatskim sudovima takvih izvanparničnih postupaka ima više nego pred ostalim jurisdikcijama koje su predmet CEPEJ-ovih analiza. Očekivano prosječno trajanje dvaju najčešćih hrvatskih izvanparničnih postupaka za 2020. odnosno 2019. godinu je samo 30 dana (2020.) odnosno šest dana (2019.) za predmete sudskog registra te 27 dana (2020.) odnosno 40 dana (2019.) za zemljišnoknjižne predmete, dok pokazatelj SA-a za izvanparnične postupke iznosi otprilike $100 \%$, što znači da domaći sudovi uspješno rješavaju sve predmete koji pristignu na sud i da se ne stvaraju zaostaci. ${ }^{40}$ Koliko izvanparnični predmeti čine značajan dio ukupnog postotka građanskih predmeta koji se vode pred sudovima, govore sljedeći podaci:

- u 2017. priljev izvanparničnih predmeta iznosio je vrlo visokih $55 \%$

- u 2018. priljev izvanparničnih predmeta bio je čak i nešto viši nego 2017. te je iznosio $59 \%$

- u 2019. priljev izvanparničnih predmeta bio je $56 \%$ dok je

- u 2020. priljev izvanparničnih predmeta bio $56 \%{ }^{41}$

Predsjednik-Vrhovnog-suda-Stalno-se-smanjuje-broj-nerijesenih-predmeta.html (18. kolovoza 2021.).

40 Statistički pregled Ministarstva pravosuđa za 2019., str. 23, 28 i 46.

41 Statistički pregled Ministarstva pravosuđa za 2017., str. 10, 24, 36; Statistički pregled Ministarstva pravosuđa za 2018., str. 9, 24 i 36; Statistički pregled Ministarstva pravosuđa za 2019., str. 11, 28 i 46; Statistički pregled Ministarstva pravosuđa za 2020., str. 11, 28 i 45. Postotak izračunan na temelju ukupnog broja primljenih predmeta te broja primljenih izvanparničnih predmeta na općinskim sudovima (Rl predmeti, ostavinski predmeti, R2 predmeti i zemljišnoknjižni predmeti) i na trgovačkim sudovima (R1 predmeti, R2 predmeti i predmeti sudskog registra). 
Gledano komparativno s drugim zemljama članicama EU-a, hrvatsko pravosuđe pripada među pravosuđa koja rješavaju iznadprosječno velik broj izvanparničnih predmeta, dok pravosuđa drugih zemalja članica EU-a imaju prosječno gledano veći postotak ulaznih parničnih i drugih sličnih predmeta koji su kompleksniji i čije rješavanje uobičajeno traje dulje nego što je to slučaj s izvanparničnim predmetima, pa usporedba pokazatelja VR-a i SA-a takvih pravosuđa s hrvatskim pravosuđem može dati iskrivljenu sliku. ${ }^{42}$ Upravo zato je podatke o pokazateljima SA-a i VR-a u građanskim predmetima potrebno promatrati i kroz navedene pokazatelje SA-a i VR-a za parnične postupke pred hrvatskim sudovima u odnosu na koje hrvatsko pravosuđe nema zadovoljavajuće podatke (hrvatski VR za parnične postupke 76 \% je lošiji od medijanskog rezultata država EU-a).

Drugi razlog zašto relativno povoljni podaci VR-a i SA-a ne mogu biti zadovoljavajući jest broj sudaca koji rade u pravosuđu. Taj je broj značajno viši od prosjeka EU-a. Hrvatsko pravosuđe ima izrazito velik broj sudaca, drugo je po broju sudaca na 100.000 stanovnika u odnosu na ostale zemlje EU-a prema podacima CEPEJ-a za 2018. godinu (jedino Slovenija ima neznatno više sudaca). U 2016. odnosno 2017. godini u EU-u prosjek je bio 21 odnosno 22 suca na 100.000 stanovnika, dok je u Hrvatskoj bio gotovo dvostruko veći i kretao se oko 43 suca na 100.000 stanovnika, što se vidi u sljedećoj tablici. ${ }^{43}$ Pritom je važno napomenuti da učinkovitost pravosuđa ne raste s brojnošću sudaca koji rade u pravosuđu pa se ovako velik broj sudaca u domaćem pravosuđu ne može opravdati željom da se poveća učinkovitost pravosuđa. ${ }^{44}$

42 CEPEJ, op. cit. u bilj. 3, str. 245.

43 Europska komisija, op. cit. u bilj. 28, tablica 35, str. 15; CEPEJ, op. cit. u bilj. 3, str. 103.

44 Bratković M., Građansko pravosuđe u službi građana, u: Barbić, J. (ur.), Europska budućnost hrvatskoga građanskog pravosuđa, HAZU, Zagreb, 2018., str. 170 - 171; Uzelac, op. cit. u bilj. 17, str. $138-142$. 
Tablica 5. Brojnost sudaca na 100.000 stanovnika ${ }^{45}$

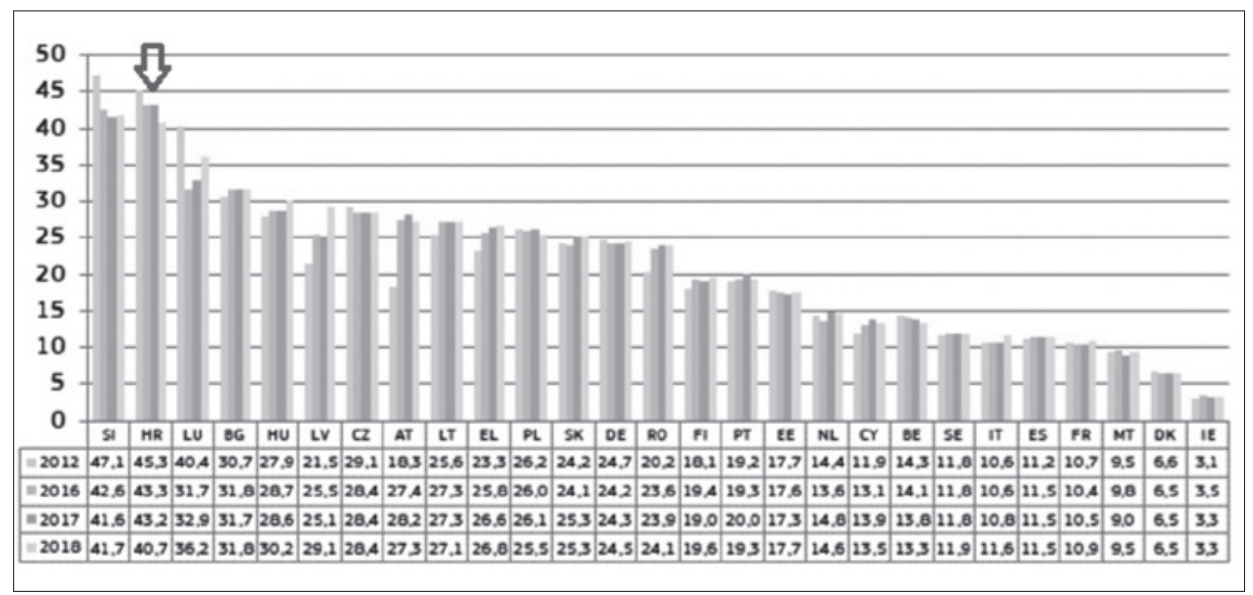

Iako su podaci u tablici dani zaključno sa stanjem u 2018. godini, može se očekivati da se pozicija Hrvatske u ovom popisu nije značajno promijenila za 2019. i 2020. jer se broj sudaca odnosno sudskih savjetnika u hrvatskom pravosuđu nije značajno mijenjao od 2018. godine do 2020. godine, u prilog čemu govore i podaci ministarstva nadležnog za pravosuđe. ${ }^{46}$ Prema tome, proizlazi da je hrvatsko pravosuđe postizalo prethodno navedene (dijelom ispodprosječne, dijelom prosječne) rezultate u pogledu VR-a i SA-a s čak dvostruko većim brojem sudaca nego što je prosječan broj sudaca u državama članicama EU-a.

Tré́i razlog zašto rezultati za pokazatelje VR-a i SA-a ne predstavljaju razlog za osobiti optimizam jest broj riješenih predmeta po sucu. Naime, ako se uzme u obzir broj riješenih predmeta po sucu, što je također vrlo važan pokazatelj učinkovitosti pravosuđa, za razdoblje 2013. - 2019. vidljivi su trendovi koji govore u prilog zaključku da se učinkovitost hrvatskog pravosuđa nije poboljšala (vidi Tablicu 6). Stoga se postavlja pitanje na koji način je moglo doći do pada broja neriješenih predmeta. Odgovor na to pitanje daju podaci iz sljedeće tablice:

45 Europska komisija, op. cit. u bilj. 28, tablica 35, str. 15. Prema metodologiji CEPEJ-a ova kategorija uključuje suce koji rade na neodređeno vrijeme.

46 Prema podacima Ministarstva pravosuđa u 2019. je u hrvatskom pravosuđu radilo ukupno 1712 sudaca, što čini 42 suca na 100.000 stanovnika (Hrvatska ima 4.072.000 stanovnika), dok je 2020. radilo 1675 sudaca, što čini 41 suca na 100.000 stanovnika. Vidi Statistički pregled Ministarstva pravosuđa za 2019., str. 6; Statistički pregled Ministarstva pravosuđa za 2020., str. 6. 
Tablica 6. Sumarni pregled pojedinih pokazatelja učinkovitosti rješavanja sudskih predmeta $^{47}$

\begin{tabular}{|l|r|r|r|r|r|r|r|}
\hline \multicolumn{1}{|c|}{ podaci o sudovima } & \multicolumn{1}{c|}{ 2013. } & \multicolumn{1}{c|}{ 2014. } & \multicolumn{1}{c|}{ 2015. } & \multicolumn{1}{c|}{ 2016. } & \multicolumn{1}{c|}{ 2017. } & \multicolumn{1}{c|}{ 2018. } & \multicolumn{1}{c|}{ 2019.48 } \\
\hline primljeno $^{49}$ & 1.189 .415 & 913.044 & 875.796 & 913.642 & 881.181 & 821.182 & 834.450 \\
\hline riješeno $^{50}$ & 1.188 .663 & 931.311 & 887.394 & 934.943 & 898.383 & 866.916 & 822.102 \\
\hline neriješeno $^{51}$ & 493.915 & 447.978 & 420,326 & 392,245 & 366,707 & 316,272 & 329,604 \\
\hline $\begin{array}{l}\text { neriješeni stari } \\
\text { predmeti (predmeti } \\
\text { koji se vode više od } \\
\text { 10 godina) }\end{array}$ & - & - & 16.934 & 15.373 & 11.971 & 9.131 & 8.176 \\
\hline $\begin{array}{l}\text { riješeno po sucu / } \\
\text { sudskom savjetniku }\end{array}$ & 479 & 371 & 361 & 384 & 374 & 369 & 354 \\
\hline
\end{tabular}

U pogledu korištenja podataka o neriješenim “starim” predmetima i broju predmeta riješenih po sucu / sudskom savjetniku iz Tablice 6, potrebna je dodatna napomena. Naime, ne postoje javno dostupni službeni podaci o broju "starih" građanskih predmeta ni sudaca / sudskih savjetnika koji rade na građanskim

47 Podaci izračunani na temelju podataka iz Statističkog pregleda Ministarstva pravosuđa za 2019. (str. 12 i 62), Statističkog pregleda Ministarstva pravosuđa za 2017. (str. 10 i 55), Statističkog pregleda Ministarstva pravosuđa za 2016. (str. 5), Statističkog pregleda Ministarstva pravosuđa za 2015. (str. 5), Statističkog pregleda Ministarstva pravosuđa za 2014. (str. 5) i Statističkog pregleda Ministarstva pravosuđa za 2013. (str. 5). Dodatno se napominje da podaci za 2020. nisu prikazani u tablici zbog specifičnosti koje su nastupile u toj godini koje su zasigurno utjecale na rad sudova.

48 Broj neriješenih predmeta na kraju 2018. i početku 2019. godine razlikuje se zbog spajanja općinskih i prekršajnih sudova, pri čemu su neriješeni prekršajni predmeti na početku 2019. godine migrirani u upisnike općinskih sudova, a njihov je broj sadržan u predmetima u radu prikazanima također u tablici (riječ je o otprilike 31.500 prekršajnih predmeta koji su postali predmeti općinskih sudova).

49 Brojka dobivena zbrajanjem građanskih, upravnih, ovršnih, trgovačkih i zemljišnoknjižnih predmeta. Autor je kontaktirao ministarstvo nadležno za poslove pravosuđa koje je 4. kolovoza 2021. potvrdilo da u navedenu brojku nisu uključeni predmeti stečaja potrošača ni predmeti sudskog registra jer je namjera da se u navedenoj kategoriji prate tzv. osnovni sudski predmeti na nacionalnoj razini, kategorizirani prema metodologiji CEPEJ-a.

50 Vidi napomenu u bilj. 49.

$51 \quad$ Vidi napomenu u bilj. 49.

52 Pojam "stari predmeti" u ovom dijelu izvješća označava predmete koji se na općinskim, trgovačkim, županijskim sudovima i Visokom trgovačkom sudu Republike Hrvatske vode više od deset godina, sukladno Statističkom pregledu Ministarstva pravosuđa za 2019. (str. 62). 
predmetima jer ministarstvo predmetne podatke vodi samo zbirno (za građanske, kaznene i prekršajne predmete zajedno). S obzirom na navedeno, podatak je izračunan na temelju podataka o svim "starim" predmetima odnosno sucima/ sudskim savjetnicima, što uključuje i "stare" negrađanske predmete (kaznene i prekršajne predmete), odnosno u pogledu općinskih i županijskih sudova suce koji sude u negrađanskim predmetima (kaznenim te prekršajnim predmetima). No, smatramo da navedeno ne bi trebalo imati utjecaj na zaključke o trendovima u pogledu (ne)učinkovitosti građanskog pravosuđa jer se može pretpostaviti da su omjeri "starih" građanskih i "starih" negrađanskih predmeta te sudaca / sudskih savjetnika koji rade na građanskim odnosno negrađanskim predmetima statistički relativno stabilni - budući da nema podataka koji bi govorili suprotno - zbog čega bi trend pada riješenih predmeta po sudu / sudskom savjetniku iskazan u Tablici 6 trebao ostati barem slično iskazan i u slučaju da postoje zasebni podaci o "starim" građanskim predmetima odnosno sucima / sudskim savjetnicima koji su radili isključivo na građanskim predmetima. U prilog tom zaključku ide i trend ukupno riješenih predmeta $\mathrm{u}$ istom razdoblju, koji su u tablici iskazani samo za građanske predmete.

Iz Tablice 6 moguće je zaključiti sljedeće o trendovima u pravosuđu u razdoblju 2013. - 2019. godine:

(a) zamjetan je izrazito pozitivan trend smanjenja neriješenih predmeta pa je tako broj neriješenih predmeta pao s 493.915 predmeta (2013. godina) na 329.604 predmeta (2019. godina), što je pad od otprilike 164.000 neriješenih predmeta ili $33 \%$ u šest godina

(b) došlo je do znatnog pada primljenih ulaznih predmeta, pa je tako 2013. godine bilo 1.189.415 ulaznih predmeta, dok je 2019. bilo 834.450 ulaznih predmeta, što je pad od gotovo 350.000 ulaznih predmeta. Drugim riječima, pad broja ulaznih predmeta koje je pravosuđe u tom razdoblju trebalo riješiti čak je dvostruko veći od pada broja neriješenih predmeta iz prethodne točke (a)

(c) podaci o ukupno riješenim predmetima i riješenim predmetima po sucu govore u prilog zaključku o ukupnom padu učinkovitosti rada sudaca / sudskih savjetnika. Tako je 2013. godine riješeno 1.188 .663 predmeta, dok je 2019. godine bilo 822.102 riješena predmeta (dakle oko 366.000 je manje riješenih sudskih predmeta), iako je broj sudaca/sudskih savjetnika ostao približno isti. ${ }^{53}$ Broj riješenih predmeta po sucu / sudskom savjetniku u istom je navedenom razdoblju (2013. - 2019.) pao s 479 riješenih

53 U 2013. godini bila su zaposlena 2482 suca / sudska savjetnika u hrvatskom pravosuđu, dok je 2019. godine bilo zaposleno 2325 sudaca / sudskih savjetnika. Podaci 
predmeta u 2013. godini na 354 riješena predmeta po sucu / sudskom savjetniku u 2019. godini, što znači da je učinkovitost sudaca / sudskih savjetnika u navedenom razdoblju pala za visokih $26 \%$ i

(d) u razdoblju 2015. - 2019. godine dolazi do značajnog pada broja tzv. neriješenih starih predmeta (neriješeni predmeti stariji od deset godina). Tako je u 2015. godini bilo 16.934 neriješena stara predmeta, dok je 2019. godine bilo 8.176 neriješenih starih predmeta, što je pad od vrlo dobrih $52 \%$ u samo četiri godine za tu skupinu predmeta.

Prema tome, i CEPEJ-ovi podaci i podaci ministarstva nadležnog za pravosuđe govore u prilog zaključku o trendu pada broja neriješenih predmeta, pri čemu je broj neriješenih predmeta i dalje visok. Dodatno, navedeni zaključak bitno dopunjavaju podaci ministarstva nadležnog za pravosuđe iz kojih se može zaključiti da uzrok padu broja neriješenih predmeta u razdoblju 2013. - 2019. godine nije povećanje učinkovitosti hrvatskog pravosuđa, nego manji broj ulaznih predmeta koje je pravosuđe trebalo rješavati, pa su se resursi pravosuđa mogli iskoristiti za rješavanje neriješenih predmeta i neriješenih starih predmeta koji se vode više od deset godina, dok pravosuđe nije $\mathrm{u}$ istom razdoblju povećalo svoju učinkovitost, štoviše, u tom razdoblju je za $26 \%$ smanjen broj riješenih predmeta po sucu / sudskom savjetniku. S druge strane, u relativno kratkom razdoblju od 2016. godine do 2019. godine došlo je do značajnog pada broja navedenih starih neriješenih predmeta od čak $47 \%$, što je pozitivan i značajan rezultat.

Navedeni podaci predstavljaju poticaj da se dodatno analizira koji konkretni dijelovi/sudovi unutar hrvatskog pravosuđa ne funkcioniraju dovoljno učinkovito. Način na koji će se navedeno pitanje analizirati jest da se utvrdi koji dijelovi pravosuđa, gledano po pojedinom sudu i po vrsti postupka, kumuliraju najveći dio neriješenih predmeta jer osim što broj neriješenih predmeta pokazuje koji dijelovi pravosuđa ne rade dovoljno učinkovito, neriješeni predmeti ujedno predstavljaju vjerojatno jedan od najvećih problema hrvatskog pravosuđa uopće, pa bi detaljnija analiza navedenog mogla pokazati neke vrijedne zaključke.

\subsection{Analiza učinkovitosti pojedinih sudova}

Od ukupnog broja neriješenih predmeta u pravosuđu u 2019. godini najveći broj neriješenih predmeta imaju općinski sudovi, i to 78 \% svih neriješenih gra-

preuzeti iz Statističkog pregleda Ministarstva pravosuđa za 2019. (str. 12) i Statističkog pregleda Ministarstva pravosuđa za 2017. (str. 10). 
đanskih predmeta u pravosuđu. ${ }^{54} \mathrm{Uz}$ njih, najveći broj neriješenih predmeta u 2019. godini, iako znatno manje, imaju županijski sudovi, i to 7 \%, te trgovački sudovi koji imaju $6 \%{ }^{55}$ Nameće se sam po sebi zaključak da kada bi se riješili svi neriješeni predmeti koje imaju općinski, županijski i trgovački sudovi, time bi se zapravo riješio jedan od većih problema hrvatskog pravosuđa jer navedeni sudovi zajedno imaju čak $91 \%$ svih neriješenih predmeta.

Gledano po broju neriješenih predmeta po sucu / sudskom savjetniku, prosječan broj neriješenih predmeta po sucu / sudskom savjetniku u pravosuđu za 2019. godinu za sve sudove iznosi 128 neriješenih predmeta po sucu / sudskom savjetniku, dok najveći broj neriješenih predmeta u 2019. godini po sucu / sudskom savjetniku imaju redom sljedeći sudovi:

- općinski sudovi (213 neriješenih predmeta po sucu / sudskom savjetniku u 2019. godini $)^{56}$

- Vrhovni sud RH (165 neriješenih predmeta po sucu / sudskom savjetniku u 2019. $\operatorname{godini})^{57} \mathrm{i}$

- trgovački sudovi (144 neriješena predmeta po sucu / sudskom savjetniku u 2019. godini). ${ }^{58}$

Stoga u nastavku slijedi detaljnija analiza učinkovitosti navedenih sudova gledano po broju neriješenih predmeta koje kreiraju navedeni sudovi te pokazateljima VR-a i SA-a. Uz navedene sudove analizirat će se i učinkovitost Vrhovnog suda RH, koji ima velik broj neriješenih predmeta po sucu / sudskom savjetniku, te Visokog trgovačkog suda RH s obzirom na važnost navedenih sudova u građanskim (trgovačkim) predmetima.

54 Izračunano na temelju podataka iz Statističkog pregleda Ministarstva pravosuđa za 2019., str. 28, 36 i 46. U izračun su uključeni i podaci stečaja potrošača te predmeti sudskog registra.

55 Ibid.

56 Izračunano na temelju podataka iz Statističkog pregleda Ministarstva pravosuđa za 2019., str. 26 i 28. U izračun su uključeni i podaci stečaja potrošača. Valja napomenuti da bi navedena brojka trebala biti i nešto viša jer su u izračunu korišteni podaci o broju svih sudaca / sudskih savjetnika u pravosuđu (dakle, koji rade i na negrađanskim predmetima) s obzirom na to da ne postoji podatak o broju sudaca / sudskih savjetnika koji rade samo na građanskim predmetima.

57 Izračunano na temelju podataka iz Statističkog pregleda Ministarstva pravosuđa za 2019., str. 59 - 60. Vidi napomenu u bilj. 56.

58 Statistički pregled Ministarstva pravosuđa za 2019., str. 44 - 46. U izračun su uključeni i podaci sudskog registra. 


\subsubsection{Općinski sudovi}

Kao što je napomenuto u točki 3.l. ovog rada, općinski sudovi imaju najviše neriješenih predmeta u odnosu na ostale sudove u RH gledano po apsolutnom broju (iako, primjerice, trgovački sudovi primaju osjetno više predmeta po sucu od općinskih sudova $)^{59}$ zbog čega je potrebno identificirati konkretne općinske sudove i konkretne vrste postupaka koji imaju nižu učinkovitost od potrebne razine. Analizirajući objavljene podatke o učinkovitosti općinskih sudova, moguće je utvrditi da je problematično dugo trajanje postupaka u kojima VR iznosi više od godine dana kod sljedećih vrsta postupaka:

- parničnih predmeta: 2019. godine VR je iznosio iznimno visokih 544 dana, a SA je iznosio vrlo niskih 80,17 \% i

- stečaja potrošača: 2019. godine VR je iznosio 432 dana, a SA je iznosio iznimno niskih 45,94\%. ${ }^{60}$

Ni u prethodnim godinama (2018. i 2017.) podaci za navedene predmete nisu znatno bolji. ${ }^{61}$ Kod ostalih vrsta postupaka općinski sudovi imali su relativno zadovoljavajuće pokazatelje VR-a i SA-a. ${ }^{62}$ Vidljivo je da za navedene vrste postupaka pokazatelji VR-a i SA-a imaju znatno lošije vrijednosti u odnosu na druge predmete pred općinskim sudovima, što znači da se može očekivati povećanje broja neriješenih predmeta kod navedenih vrsta postupaka jer učinkovitost općinskih sudova u pogledu navedenih vrsta postupaka nije na zadovoljavajućoj razini. Svakako je za navedene vrste postupaka potrebno poduzeti odgovarajuće mjere da bi se učinkovitost općinskih sudova povećala te da bi se izbjeglo dodatno povećanje neriješenih predmeta.

Valja napomenuti da je ovako visok VR kod općinskih sudova u promatranim vrstama postupaka dodatno neprihvatljiv imajući u vidu brojnost navedenih postupaka. Tako je u 2019. broj primljenih parničnih predmeta iznosio 107.893, a broj predmeta stečaja potrošača 96.196, što čini 25 \% svih građanskih predmeta koje su općinski sudovi primili u toj godini.

Upravo zbog brojnosti navedenih vrsta postupaka jasno je da ako se ne poduzmu odgovarajuće mjere za povećanje učinkovitosti sudova kada postupaju u

59 U 2019. godini trgovački sudovi primali su 958 predmeta po sucu / sudskom savjetniku, dok su općinski sudovi primali 701 predmet po sucu / sudskom savjetniku. Statistički pregled Ministarstva pravosuđa za 2019., str. 15 i 16.

Statistički pregled Ministarstva pravosuđa za 2018., tablica 14, str. 24 - 25; Statistički pregled Ministarstva pravosuđa za 2019., str. 28.

Ibid.

62 Navedeno znači da je pokazatelj VR-a bio manji od 365 dana, a pokazatelj SA-a kretao se oko 100 \%. Vidi Statistički pregled Ministarstva pravosuđa za 2019., str. 28. 
navedenim vrstama postupaka, može se očekivati da će se ukupni broj neriješenih predmeta općinskih sudova značajno povećati. Takvo povećanje neriješenih predmeta dodatno bi negativno utjecalo na već nepovoljnu sliku pravosuđa u cjelini s obzirom na brojnost i važnost navedenih predmeta te na veliki udio neriješenih predmeta općinskih sudova u ukupnom broju neriješenih predmeta u pravosuđu - neriješeni predmeti na općinskim sudovima u 2019. godini iznose 78 \% svih neriješenih građanskih predmeta hrvatskog pravosuđa. ${ }^{63}$

Dodatno pitanje je i koji konkretni općinski sudovi nemaju zadovoljavajuće pokazatelje VR-a i SA-a. Nažalost, ne postoje javno dostupni službeni podaci koji bi odgovorili na navedeno pitanje s obzirom na to da se podaci pojedinačnih općinskih sudova vode samo zbirno (za građanske, kaznene i prekršajne ${ }^{64}$ predmete zajedno).

Međutim, moguće je tvrditi da su i takvi zbirni rezultati općinskih sudova mjerodavni jer pokazuju učinkovitost pojedinog općinskog suda u cjelini, pa se može očekivati da će sudovi s nižom zbirnom učinkovitosti u odnosu na druge općinske sudove imati takvu nižu učinkovitost i u pogledu (samo) građanskih predmeta. To vrijedi osobito zato što i neki javno objavljeni podaci i analize podataka dostupni na e-predmetu govore u prilog da postoji korelacija niže zbirne učinkovitosti sudova (koja uključuje zbirne podatke za građanske, kaznene i prekršajne predmete zajedno) s nižom učinkovitosti sudova u građanskim predmetima. ${ }^{65}$

Iz javno dostupnih podataka dolazi se do zaključka da neki općinski sudovi već nekoliko godina ostvaruju lošije rezultate vezano uz pokazatelje VR-a i SA-a u odnosu na druge općinske sudove, što se reflektira u visokom broju neriješenih predmeta. U tom smislu moguće je izdvojiti sudove prikazane u sljedećoj tablici:

${ }^{63}$ Izračunano na temelju podataka iz Statističkog pregleda Ministarstva pravosuđa za 2019., str. 28, 36 i 46.

64 2019. godine provedeno je spajanje prekršajnih i općinskih sudova.

65 Vidi https://epredmet.github.io/ (29. listopada 2021.). Ondje su prikazani podaci iz stranice e-Predmet iz kojih slijedi da su sudovi označeni u Tablici 7 u ovom radu također ostvarivali lošije rezultate u pogledu građanskih predmeta. Primjera radi, Općinski sud u Splitu u razdoblju od 2015. do 2019. ostvario je prosječno stvarno trajanje za građanske predmete koji se vode u parničnom upisniku $\mathrm{P}$ od gotovo 1500 dana (dakle četiri godine). Jednako tako iz navedenih podataka proizlazi da, ako se gledaju samo građanski predmeti koji se vode u parničnom upisniku P koji su rješavani na Općinskom građanskom sudu, onda se za razdoblje 2015. - 2019. dobivaju vrijednosti VR od 771, 745, 651, 580 i 892 dana, dakle nepovoljno visok VR. Navedeni podaci govore u prilog zaključku da postoji korelacija između niže zbirne učinkovitosti i niže učinkovitosti sudova u građanskim predmetima te da parnični predmeti predstavljaju one predmete u kojima domaći sudovi postupaju s nezadovoljavajućom, nižom učinkovitosti. 
Tablica 7. Podaci o pokazateljima učinkovitosti sudova ${ }^{66}$

\begin{tabular}{|c|c|c|c|c|c|c|c|}
\hline br. & sud & godina & VR & SA & $\left|\begin{array}{c}\text { neriješeni } \\
\text { predmeti }\end{array}\right|$ & \begin{tabular}{|c|} 
broj \\
riješenih \\
predmeta po \\
rješavatelju \\
\end{tabular} & $\begin{array}{l}\text { broj riješenih predmeta } \\
\text { po rješavatelju u } \\
\text { odnosu na prosjek kod } \\
\text { općinskih sudova }^{67}\end{array}$ \\
\hline \multirow{3}{*}{1.} & \multirow{3}{*}{\begin{tabular}{|c|} 
Općinski \\
građanski sud \\
u Zagrebu
\end{tabular}} & 2017. & 351 & $102,44 \%$ & 63.226 & 356 & $24,04 \%$ \\
\hline & & 2018. & 318 & $115,34 \%$ & 50.644 & 302 & $16,15 \%$ \\
\hline & & 2019. & 414 & $92,75 \%$ & 50.664 & 250 & $-3,47 \%$ \\
\hline \multirow{3}{*}{2.} & \multirow{3}{*}{$\begin{array}{c}\text { Općinski sud } \\
\text { u Splitu }\end{array}$} & 2017. & 341 & $109,42 \%$ & 29.374 & 228 & $-20,56 \%$ \\
\hline & & 2018. & 370 & $106,62 \%$ & 27.762 & 192 & $-26,15 \%$ \\
\hline & & 2019. & 478 & $86,07 \%$ & 27.477 & 172 & $-33,59 \%$ \\
\hline \multirow{3}{*}{3.} & \multirow{3}{*}{$\begin{array}{c}\text { Općinski sud } \\
\text { u Rijeci }\end{array}$} & 2017. & 317 & $108,03 \%$ & 18.416 & 219 & $-23,69 \%$ \\
\hline & & 2018. & 324 & $106,14 \%$ & 17.336 & 213 & $-18,08 \%$ \\
\hline & & 2019. & 418 & $88,04 \%$ & 22.310 & 224 & $-13,51 \%$ \\
\hline \multirow{3}{*}{4.} & \multirow{3}{*}{$\begin{array}{c}\text { Općinski sud } \\
\text { u Čakovcu }\end{array}$} & 2017. & 174 & $105,75 \%$ & 2.444 & 270 & $-5,92 \%$ \\
\hline & & 2018. & 190 & $103,73 \%$ & 2.283 & 209 & $-19,62 \%$ \\
\hline & & 2019. & 176 & $98,26 \%$ & 3.369 & 269 & $3,86 \%$ \\
\hline \multirow{3}{*}{5.} & \multirow{3}{*}{$\begin{array}{c}\text { Općinski sud } \\
\text { u Šibeniku }\end{array}$} & 2017. & 392 & $98,25 \%$ & 9.443 & 238 & $-17,07 \%$ \\
\hline & & 2018. & 380 & $114,07 \%$ & 8.466 & 214 & $-17,69 \%$ \\
\hline & & 2019. & 295 & $108,75 \%$ & 9.805 & 269 & $3,86 \%$ \\
\hline \multirow{3}{*}{6.} & \multirow{3}{*}{\begin{tabular}{|c|} 
Općinski \\
sud u \\
Dubrovniku $^{68}$
\end{tabular}} & 2017. & 449 & $98,44 \%$ & 8.617 & 242 & $-15,68 \%$ \\
\hline & & 2018. & 382 & $110,92 \%$ & 7.867 & 228 & $-12,31 \%$ \\
\hline & & 2019. & 456 & $90,82 \%$ & 8.494 & 200 & $-22,78 \%$ \\
\hline \multirow{3}{*}{7.} & \multirow{3}{*}{$\begin{array}{l}\text { Općinski } \\
\text { radni sud u } \\
\text { Zagrebu } \\
\end{array}$} & 2017. & 335 & $128,51 \%$ & 2.963 & 147 & $-48,78 \%$ \\
\hline & & 2018. & 369 & $72,98 \%$ & 4.677 & 210 & $-19,23 \%$ \\
\hline & & 2019. & 456 & $95,37 \%$ & 4.870 & 162 & $-37,45 \%$ \\
\hline \multirow{3}{*}{8.} & \multirow{3}{*}{$\begin{array}{c}\text { Općinski sud } \\
\text { u Osijeku }\end{array}$} & 2017. & 132 & $107,19 \%$ & 5.265 & 235 & $-18,12 \%$ \\
\hline & & 2018. & 162 & $102,37 \%$ & 4.999 & 205 & $-21,15 \%$ \\
\hline & & 2019. & 258 & $77,65 \%$ & 8.371 & 201 & $-22,39 \%$ \\
\hline \multirow{3}{*}{9.} & \multirow{3}{*}{$\begin{array}{c}\text { Općinski sud } \\
\text { u Virovitici }\end{array}$} & 2017. & 115 & $105,74 \%$ & 1.591 & 265 & $-7,67 \%$ \\
\hline & & 2018. & 136 & $105,15 \%$ & 1.404 & 210 & $-19,23 \%$ \\
\hline & & 2019. & 109 & $98,67 \%$ & 1.903 & 254 & $-1,93 \%$ \\
\hline \multirow{3}{*}{10.} & \multirow{3}{*}{$\begin{array}{c}\text { Općinski sud } \\
\text { u Zadru }\end{array}$} & 2017. & 261 & $101,88 \%$ & 9.724 & 234 & $-18,47 \%$ \\
\hline & & 2018. & 276 & $101,43 \%$ & 9.545 & 221 & $-15,00 \%$ \\
\hline & & 2019. & 270 & $92,57 \%$ & 12.486 & 231 & $-10,81 \%$ \\
\hline
\end{tabular}

66 Podaci preuzeti te izračunani na temelju dostupnih podataka na stranici Ministarstva pravosuđa https://sudovi.hr/hr/statistike/rezultati-rada-sudova (18. kolovoza 2021.).

67 Negativan broj znači da je toliko postotaka predmetni sud imao manju učinkovitost u odnosu na prosječne rezultate svih općinskih sudova u toj godini (gledano po broju riješenih predmeta po rješavatelju). Pozitivan broj znači da je predmetni sud imao toliko veću učinkovitost od prosječnih rezultata ostalih općinskih sudova.

68 Neznatan pad neriješenih predmeta na Općinskom sudu u Dubrovniku unatoč lošim pokazateljima VR-a i SA-a može se objasniti povećanjem broja zaposlenih sudaca na tom sudu. 
Iz navedenih podataka jasno se može vidjeti zašto predmetni sudovi imaju velik broj neriješenih predmeta već nekoliko godina. Jedino Općinski građanski sud u Zagrebu ima djelomično pozitivne podatke u skladu s kojima je došlo do značajnog smanjenja broja neriješenih predmeta iz prethodnih godina. U odnosu na sudove navedene $\mathrm{u}$ tablici, potrebno je navesti da redoslijed sudova ne predstavlja mjerilo koji je sud bolji ili lošiji. Iako kod pojedinih sudova postoje određeni trendovi poboljšanja, oni su nedostatni te se svakako može konstatirati da gore u tablici istaknuti općinski sudovi nemaju zadovoljavajuće pokazatelje VR-a i SA-a, odnosno nemaju zadovoljavajući broj riješenih predmeta po rješavatelju u odnosu na prosjek broja riješenih predmeta po rješavatelju za razdoblje 2017. - 2019., što rezultira visokim brojem neriješenih predmeta, odnosno negativnim trendom povećanja neriješenih predmeta na promatranom sudu.

Ne postoje javno dostupni službeni podaci koji bi dali odgovor na pitanje zašto navedeni sudovi imaju lošije pokazatelje učinkovitosti, odnosno zašto imaju veći broj neriješenih predmeta. Stoga je na nadležnim odgovornim osobama (prije svega na predsjednicima sudova i ministru nadležnom za poslove pravosuđa) da utvrde koji su uzroci lošijih rezultata učinkovitosti navedenih sudova u odnosu na druge sudove te da kreiraju mjere da se uzroci takvih rezultata konačno počnu rješavati.

\subsubsection{Trgovački sudovi}

Analizirajući pokazatelj VR-a za sve vrste postupaka koji se vode pred trgovačkim sudovima, kako je prikazano u statističkim pregledima Ministarstva pravosuđa, vidljivo je da je VR za 2018. najlošiji za parnične postupke, u kojima je iznosio čak 374 dana. Ti podaci su se u 2019. godini poboljšali pa je tako VR iznosio za parnične postupke 320 dana, no uz izvrstan SA od 121,47 \%. Za ostale vrste postupaka trgovački sudovi imali su uglavnom povoljne pokazatelje, uz manja odstupanja. ${ }^{69}$

Navedeni trend poboljšanja učinkovitosti trgovačkih sudova vidi se i na broju neriješenih predmeta, čiji je broj u 2018. godini iznosio 29.444, da bi pao na 24.884 neriješena predmeta u 2019. godini, što predstavlja pad od $16 \% \mathrm{u}$ samo jednoj godini. ${ }^{70}$

69 Vidi Statistički pregled Ministarstva pravosuđa za 2018., str. 36.; Statistički pregled Ministarstva pravosuđa za 2019., str. 46.

70 Vidi Statistički pregled Ministarstva pravosuđa za 2018., str. 36; Statistički pregled Ministarstva pravosuđa za 2019., str. 46. 
Analizirajući pokazatelje VR-a i SA-a te broj neriješenih predmeta za konkretne trgovačke sudove, izdvaja se samo Trgovački sud u Zagrebu s velikim brojem neriješenih predmeta, čiji su VR i SA u razdoblju od 2017. do 2019. godine bili kako slijedi: ${ }^{71}$

\begin{tabular}{|c|c|c|c|c|}
\hline \multirow{2}{*}{ sud } & godina & VR & SA & $\begin{array}{c}\text { neriješeni } \\
\text { predmeti }\end{array}$ \\
\hline \multirow{3}{*}{ Trgovački sud u Zagrebu } & 2017. & 365 & $121,32 \%$ & 16.293 \\
\cline { 2 - 5 } & 2018. & 390 & $102,24 \%$ & 14.102 \\
\cline { 2 - 5 } & 2019. & 336 & $109,21 \%$ & 12.033 \\
\hline
\end{tabular}

Nejasno je zašto se Trgovački sud u Zagrebu izdvaja po nešto lošijim podacima od ostalih trgovačkih sudova u RH te bi navedeno trebalo biti predmetom dodatne analize. Ne postoje javno dostupni službeni podaci koji bi dali odgovor na to pitanje. Čini se da Trgovački sud u Zagrebu nije opterećeniji od ostalih trgovačkih sudova u RH, pa to ne bi trebao biti razlog lošijih rezultata. ${ }^{72}$

Ostali trgovački sudovi su, prosječno gledano, za navedeno razdoblje od 2017. do 2019. godine imali povoljan pokazatelj VR-a (manje od jedne godine) i povoljan SA (više od 100 \%), uz smanjenje broja neriješenih predmeta, dakle, imali su zadovoljavajuću razinu učinkovitosti. Povijesni podaci o ukupnom broju neriješenih predmeta dodatno podupiru navedeni zaključak: ukupan broj neriješenih predmeta na trgovačkim sudovima smanjio se $44 \%$ od 2015. do 2019. godine. ${ }^{73}$

Dakle, vidljivo je da postoje pozitivni trendovi kod trgovačkih sudova $\mathrm{u}$ pogledu neriješenih predmeta te da navedeni sudovi imaju zadovoljavajuću učinkovitost zbog čega oni ne doprinose nižoj razini učinkovitosti hrvatskog pravosuđa u cjelini. No, valja istaknuti da navedeno ne znači da ne postoji prostor za dodatna poboljšanja učinkovitosti kod navedenih sudova kako bi navedeni rezultati bili još bolji.

71 Preuzeto sa stranice https://sudovi.hr/index.php/hr/statistike/trgovacki-sudovi (18. kolovoza 2021.).

72 Prema dostupnim podacima Ministarstva prosječno opterećenje trgovačkih sudova u RH u razdoblju 2017. - 2020. gledano po broju primljenih predmeta po rješavatelju iznosilo je 150 predmeta po rješavatelju, dok je kod Trgovačkog suda u Zagrebu to opterećenje neznatno veće (162 primljena predmeta po rješavatelju). Izračunano na temelju podataka dostupnih na https://sudovi.hr/hr/statistike/trgovacki-sudovi (4. kolovoza 2021.).

73 Pad s 44.236 neriješenih predmeta na 24.884 neriješena predmeta. Vidi Statistički pregled Ministarstva pravosuđa za 2019., str. 45. 


\subsection{3. Županijski sudovi}

Podaci o radu županijskih sudova navode na zaključak da navedeni sudovi postupaju učinkovito pa ne predstavljaju doprinos nižoj učinkovitosti hrvatskih sudova. $^{74}$ Tako su navedeni sudovi smanjili broj neriješenih predmeta s 52.354 predmeta u 2015. godini na 28.412 predmeta u 2019. godini pa sada njihov udio u neriješenim predmetima iznosi $7 \% .^{75}$

Prema tome, iz navedenih statističkih podataka proizlazi da županijski sudovi imaju zadovoljavajuću razinu učinkovitosti, ne pridonose neučinkovitosti pravosuđa, no navedeno ne znači da ne postoji prostor za napredak kod učinkovitosti navedenih sudova. ${ }^{76}$

\subsubsection{Visoki trgovački sud $R H$}

Podaci o radu Visokog trgovačkog suda RH upućuju na to da je navedeni sud znatno poboljšao učinkovitost zbog čega navedeni sud ne predstavlja doprinos nižoj učinkovitosti hrvatskih sudova. Tako je u četiri godine (2017. - 2020.) broj neriješenih predmeta pao za visokih 65 \% (s 12.428 neriješenih predmeta u 2017. na 4459 u 2020. godini) uz vrlo visok SA (prosječno $142 \%$ u razdoblju 2017. - 2020.) i VR koji ima trend smanjenja (za visokih $53 \%$ ), a sve to uz sličan broj sudaca / sudskih savjetnika tijekom promatranog razdoblja. ${ }^{77}$

Iz navedenih statističkih podataka proizlazi da Visoki trgovački sud RH ne pridonosi nižoj učinkovitosti pravosuđa, no navedeno ne znači da ne postoji prostor za napredak kod učinkovitosti navedenog suda.

\subsubsection{Vrhovni sud $R H$}

Vrhovni sud RH nema, gledano u apsolutnim brojevima, značajan broj neriješenih predmeta (u 2018. bilo je 14.926 neriješenih predmeta, dok je u 2019.

74 Prosječan SA svih županijskih sudova bio je 106 \%, a VR 140 dana za 2019. godinu. Vidi Statistički pregled Ministarstva pravosuđa za 2019., str. 40. Slični dobri podaci o učinkovitosti županijskih sudova bili su i u 2018. godini i 2017. godini.

75 Ibid., str. 35.

76 I osobno iskustvo autora te nekoliko kolega odvjetnika s kojima je autor kontaktirao u vezi s navedenim podacima jest da su županijski sudovi znatno ubrzali rad.

77 Izračunano na temelju podataka dostupnih na https://sudovi.hr/hr/statistike/visoki-trgovacki-sud-republike-hrvatske (10. listopada 2021.). Broj rješavatelja u navedenom razdoblju kretao se od 59 do 63 sudaca / sudskih savjetnika. 
bilo 13.243 neriješena predmeta). No, s obzirom na to da navedeni sud ima značajan broj neriješenih predmeta po sucu te da je ipak riječ o najvišem sudu u Hrvatskoj koji bi trebao biti ogledni primjer stanja pravosuđa, u nastavku se izlaže kratka analiza učinkovitosti navedenog suda.

$\mathrm{S}$ izrazito visokim brojem neriješenih predmeta, ovaj Sud umjesto da ispunjava svoju ustavnu dužnost i kao najviši sud u Hrvatskoj osigurava jedinstvenu primjenu prava i ravnopravnost svih u njegovoj primjeni, Vrhovni sud RH nažalost ima vrlo negativan omjer neriješenih predmeta po sucu (čak 236 neriješenih predmeta po sucu u 2018. te 207 neriješenih predmeta po sucu u 2019. u građanskim predmetima). ${ }^{78}$ Takav rezultat velikim je dijelom posljedica i preliberalnih procesnih propisa kojima je omogućeno da Vrhovni sud RH djeluje kao treći stupanj odlučivanja, što nije njegova ustavnopravna pozicija. Primjera radi, u literaturi se s pravom ističe da vrhovni sudovi u Norveškoj i Finskoj donose oko 80 odluka godišnje u građanskim stvarima, dok u Danskoj vrhovni sud donosi godišnje više od 200 odluka. ${ }^{79}$ Vrhovni sud RH rješava znatno veći broj predmeta: tako je u razdoblju od 2015. do 2019. svaku pojedinu godinu riješio više od 7.500 predmeta po godini (2018. godine je riješio čak 11.280 predmeta), od čega je većina građanskih predmeta (u 2019. godini primljeno je otprilike 2000 kaznenih predmeta i 6000 građanskih predmeta). Stoga bi se moglo reći da je znatan dio razloga što Vrhovni sud RH ima ovako velik broj neriješenih predmeta po sucu upravo neodgovarajući, preliberalni režim mogućnosti ulaganja pravnih lijekova Vrhovnom sudu RH.

Čini se da je zakonodavac odlučio pristupiti navedenom problemu na način da se smanji mogućnost ulaganja revizije. Iako su izmjene zakonodavstva u 2019. godini (prije svega izmjene Zakona o parničnom postupku kojima se predviđa revizija po dopuštenju Vrhovnog suda $\mathrm{RH}^{80}$ ) išle u smjeru restriktivnijeg režima kako bi manji broj predmeta stizao Vrhovnom sudu RH na odlučivanje, ostaje vidjeti hoće li zaista te zakonodavne mjere polučiti željeni rezultat.

78 Izračunano za VSRH na temelju podataka iz Statističkog pregleda Ministarstva pravosuđa za 2018., str. 52 i 53, te Statističkog pregleda Ministarstva pravosuđa za 2019., str. 59 i 60.

79 Bratković, op. cit. u bilj. 44, str. 170 - 171.

80 Zakon o parničnom postupku, Narodne novine, br. 53/1991, 91/1992, 58/1993, 112/1999, 88/2001, 117/2003, 88/2005, 02/2007, 84/2008, 96/2008, 123/2008, 57/2011, 148/2011, 25/2013, 89/2014, 70/2019. 


\section{ZAKLJUČAK}

Iako postoje pozitivni pomaci u pojedinim statističkim pokazateljima hrvatskog pravosuđa (kao što su pad broja neriješenih predmeta i starih neriješenih predmeta), navedeni pozitivni pomaci nisu rezultat povećane učinkovitosti domaćeg pravosuđa u smislu većeg broja riješenih predmeta nego drugih faktora, i to ponajprije smanjenog broja predmeta koji ulaze u pravosuđe. S druge strane, podatak o padu broja starih neriješenih predmeta (predmeti koji se vode više od deset godina) u promatranom razdoblju govori u prilog tome da je pravosuđe $u$ isto vrijeme resurse koji su se oslobodili zbog manjeg broja ulaznih predmeta fokusiralo na rješavanje starih neriješenih predmeta. ${ }^{81}$

U pogledu vrsta postupaka osobito se ističu parnični predmeti kao predmeti u kojima je učinkovitost sudova nezadovoljavajuće niska, dok se u pogledu vrste sudova ističu općinski sudovi kao sudovi s nezadovoljavajućom učinkovitosti. No, valja primijetiti da se nezadovoljavajuća učinkovitost sudova očituje u neadekvatnoj učinkovitosti kojom sudovi riješe predmet, što ne podrazumijeva automatski da je sam sud koji vodi predmet postupao na neučinkovit način. Naime, učinkovitost pravosuđa u rješavanju predmeta ne ovisi samo o ažurnom postupanju konkretnih sudaca koji vode konkretan predmet - postoji cijeli niz vanjskih faktora koji su izvan izravne kontrole sudova, no umanjuju učinkovitost sudova u rješavanju sudskih predmeta. Tako se u literaturi te dostupnim analizama stanja pravosuđa spominju sljedeći uzroci smanjene učinkovitosti hrvatskog pravosuđa, koje je moguće razdijeliti u grupe: (l) uzroci vezani uz postupanje i ažurnost samih sudaca kao što su nedovoljno proaktivno upravljanje prvostupanjskim sudskim postupkom, uključujući nepotrebne i prečeste odgode ročišta ${ }^{82}$, postupanje viših sudova u povodu uloženih pravnih lijekova ${ }^{83}$ i (2) vanjski faktori koji ne predstavljaju postupanje samih sudaca/sudova, ali umanjuju učinkovitost sudova u rješavanju sudskih predmeta kao što su neu-

81 Vidi Visoki trgovački sud RH, Izvod iz zapisnika sa sastanka predsjednika trgovačkih sudova, Zagreb, Visoki trgovački sud RH, posl.br. Su-567/06, 19. listopada 2006., u kojem je navedeno da stari neriješeni predmeti imaju prednost u rješavanju, dostupno na: https://www.vtsrh.hr/uploads/Novosti/Dokumenti/5\%20preglednik\%20mjera/3. Jedinstveni_plan_rjesavanja_svih_predmeta.doc (22. listopada 2021.).

82 World Bank, Project Performance Assessment Report, Croatia: Justice Sector Support Project, World Bank, Washington, DC, 2020., str. vii - viii te 2; Uzelac, op. cit. u bilj. 11 , str. 124 - 125; World Bank, op. cit. u bilj. 11, str. 17 - 18 i 23 - 25, 42 - 43.

83 Vidi World Bank, op. cit. u bilj. 11, str. 17 - 18 i 23 - 25, 42 - 43; Uzelac, op. cit. u bilj. 14, str. 229 - 257; World Bank, Justice Sector Public Expenditure and Institutional Review, Resourcing the Justice Sector for Efficiency and Performance, World Bank, Washington, DC, 2014., str. i - iii, 44 - 45; World Bank, op. cit. u bilj. 82, str. 12. 
činkovita sudska dostava ${ }^{84}$, nedovoljna razina digitalizacije pravosuđa ${ }^{85}$, neadekvatna fizička infrastruktura sudova ${ }^{86}$, prečeste izmjene propisa ${ }^{87}$, ponašanje stranaka i njihovih punomoćnika u tijeku postupka ${ }^{88}$, neadekvatno vrednovanje rada sudaca te općenito neadekvatno korištenje metoda upravljanja i razvoja ljudskih resursa. ${ }^{89}$ Nažalost, kao što je navedeno u ovom radu, ne postoje javno objavljeni statistički podaci koji bi dali odgovor na pitanje koji od navedenih razloga i u kojoj mjeri utječu na smanjenu učinkovitost hrvatskih sudova.

Mnogo je reformi pravosuđa i izmjena zakonodavstva najavljivano radi poboljšanja učinkovitost pravosuđa. Taj se trend održao i do sada. ${ }^{90}$ Međutim, da bi reforme imale sveobuhvatan i dugotrajni učinak, potrebno je da im se pristupi strateški, odmjereno i na temelju objektivno mjerljivih statističkih podataka te je potrebno da takva reforma bude usmjerena na sve relevantne faktore koji utječu na nezadovoljavajuću učinkovitost sudova. ${ }^{91}$ Kao što je ovaj rad pokazao, nedostaju precizni statistički podaci koji bi istaknuli stvarne i mjerljive uzroke nezadovoljavajuće učinkovitosti domaćeg pravosuđa, što je jedna od bitnih prepreka u provođenju takve sveobuhvatne reforme pravosuđa.

Pravosudna teorija i praksa identificirali su konkretne mjere koje stoje na raspolaganju tijelima kako bi se rasvijetlili konkretni uzroci smanjene učinkovitosti pravosuđa te je na nadležnim tijelima da ispravno identificiraju navedene uzroke i da onda poduzmu ciljane mjere kako bi se problemi riješili na njihovu izvoru. Za rješavanje navedenih razloga smanjene učinkovitosti pravosuđa korisno je usporediti iskustva drugih država koja su vrlo vrijedan pokazatelj koja mjera se pokazala korisnom u eliminiranju uzroka problema, no imajući na

84 Vidi Uzelac, op. cit. u bilj. 10; Uzelac op. cit. u bilj. 14, str. 229 - 257; Sessa, Đ.; Katić, D., Dostava izvan Republike Hrvatske, Pravosudna akademija, Zagreb, 2017., str. 4; Uzelac et al., op. cit. u bilj. 10, str. 455 - 468.

85 Vidi Uzelac, op. cit. u bilj. 11, str. 124 - 125; World Bank, op. cit. u bilj. 11, str. 38 - 41.

86 Uzelac, op. cit. u bilj. 11, str. 124 - 125; World Bank, op. cit. u bilj. 11, str. 36 - 38 i 42 - 48; World Bank, op. cit. u bilj. 82, str. 13 - 15.

87 World Bank, op. cit. u bilj. 11, str. 6, 10 - 11; World Bank, op. cit. u bilj. 82, str. 13.

88 Uzelac, op. cit. u bilj. 13, str. 125; World Bank, op. cit. u bilj. 13, str. 12.

89 Vidi Uzelac, op. cit. u bilj. 11, str. $124-125$.

90 Vidi izjave ministra nadležnog za pravosuđe u kojima se najavljuju nove reforme pravosuđa, gdje je među ostalim navedeno: "Planira se i učinkovitiji način dostavljanja sudskih odluka, edukacija te sigurnosna provjera sudaca. U okviru Nacionalnog plana otpornosti i oporavka predviđeno je 13 reformi.", dostupno na: https://www. tportal.hr/vijesti/clanak/malenica-o-presudi-hernadiju-reformi-pravosuda-i-dobronicu-vjerujem-da-cemo-imati-iskreni-dijalog-20211025 (29. listopada 2021.).

91 Tako i Bratković, op. cit. u bilj. 46, str. 178 - 180. 
umu da svaka mjera mora biti prilagođena specifičnostima pravosuđa u kojem se provodi. ${ }^{92}$ Automatsko provođenje neke mjere, koja je čak i donijela pozitivne rezultate u inozemstvu, bez prilagođavanja lokalnim hrvatskim uvjetima, moglo bi rezultirati neželjenim učincima. ${ }^{93}$ Preostaje se nadati da će biti dovoljno odlučnosti kod nadležnih tijela i osoba da zaista i provedu navedene korake.

\section{BIBLIOGRAFIJA}

Bove, V.; Elia, L., The Judicial System and Economic Development Across EU Member States, JRC Technical Report, Publications Office of the EU, Luxembourg, 2017.

Bratković, M., Građansko pravosuđe u službi građana, u: Barbić, J. (ur.), Europska budućnost hrvatskoga građanskog pravosuđa, HAZU, Zagreb, 2018., str. 161 - 183.

Bülent, D., Effect of Judicial Independence to FDI into Eastern Europe and South Asia, Munich Personal RePec Archive, München, 2012.

CEPEJ, European judicial systems, Efficiency and quality of justice, CEPEJ studija br. 26, Vijeće Europe, Strasbourg, 2018.

Dimitrova-Grajzl, V.; Grajzl, P.; Sustersic, J.; Zajc, K., Court Output, Judicial Staffing, and the Demand for Court Services: Evidence from Slovenian Courts of First Instance, International Review of Law and Economics, vol. 32, br. 1, 2012. str. $19-29$.

European Network of Councils for the Judiciary (ENCJ), Judicial Reform in Europe, Report 2011-2012, ENCJ, Dublin, 2013.

Europska komisija, The 2017 EU Justice Scoreboard, Luxembourg, 2017.

Europska komisija, The 2020 EU Justice Scoreboard, Luxembourg, 2020.

Europska komisija, The 2020 EU Justice Scoreboard Quantitative Data, Bruxelles, 2020.

Grubišin, M.; Vlahek, I.; Milić, N.; Pomykalo, V.; Oreb, Z.; Minauf, M.; Jakovac, V., Vodič kroz pravosuđe, Ministarstvo pravosuđa, Zagreb, 2016.

Izvješće predsjednika Vrhovnog suda RH o stanju sudbene vlasti za 2013., 2017., 2019. i 2020.

Langbroek, P.; Kleiman, M.; Lee, C. G.; Schauffler, R.; Ostrom, B., Backlog Reduction Programs and Weighted Caseload Methods for South East Europe, Two Comparative Inquiries, Regional Cooperation Council, FINAL REPORT, 2016.

92 Ibid.

93 Ibid. 
Masuch, K.; Anderton, R.; Setzer, R.; Benalal, N., Structural Policies in the Euro Area, Europska centralna banka (ECB), Occasional Paper Series No. 210, Frankfurt na Majni, 2018.

Međunarodni monetarni fond, Europe: Europe Hitting its Stride, Regional Economic Outlook, 11/2017, MMF, Washington, 2017.

Ontanu, E. A.; Velicogna, M., The challenge of comparing EU Member States judicial data Court Output, Oñati Socio-Legal Series, vol. 11, br. 2, 2021., str. 446 - 480.

Organisation for Economic Cooperation and Development (OECD), Judicial performance and its determinants: a cross-country perspective, A Going For Growth Report, Policy Paper No. 5, OECD, Pariz, 2013.

Sessa, Đ.; Katić D., Dostava izvan Republike Hrvatske, Pravosudna akademija, Zagreb, 2017.

Statistički pregledi Ministarstva pravosuda za 2006., 2012., 2013., 2014., 2015., 2016., 2017., 2019.

United States Agency for International (USAID), Best practices guide - Backlog Prevention \& Reduction Measures for Courts in Serbia, Beograd, 2012.

Uzelac, A., The Rule of Law and the Croatian Judicial System: Court Delays as a Barrier on the Road to European Accession, u: Frosini, J.; Lupoi, M. A.; Marchesiello, M. (ur.), A European Space of Justice, Longo, Ravenna, 2006., str. 87 - 108.

Uzelac, A., Efficiency of European Justice Systems. The strength and weaknesses of the CEPEJ evaluations, International Journal of Procedural Law, vol. 1, br. 1, 2011. str. $106-146$.

Uzelac, A., Dostava sudskih pismena, hrvatska iskustva nakon novele Zakona o parničnom postupku iz 2008. i pouke koje se iz njih mogu izvući, dostupno na: https:// pravosudje.ba/vstv/faces/docservlet?p_id_doc $=4206$

Uzelac, A., Features and Shortcomings of Appellate Review in Civil and Administrative Cases in Croatia, u: Uzelac, A.; van Rhee, R. (ur.), Nobody's Perfect, Comparative Essays on Appeals and Other Means of Recourse Against Judicial Decisions in Civil Matters, Intersentia, Cambridge - Antwerp - Portland, 2014., str. 227 - 255.

Uzelac, A.; Bratković, M.; Mileković, E., Dostava preko sudske oglasne ploče: mogućnosti i ograničenja, u: Šago, D. et al. (ur.), Zbornik radova s IV. međunarodnog savjetovanja Aktualnosti građanskog procesnog prava - nacionalna i usporedna pravnoteorijska i praktična dostignuća, Pravni fakultet Sveučilišta u Splitu, Split, 2018., str. $455-468$

Uzelac, A., Ustavno pravo na žalbu u građanskim stvarima: jamstvo ispravnog pravosudenja ili relikt prošlosti, u: Uzelac, A.; Garašić, J.; Maganić, A. (ur.), Djelotvorna pravna zaštita u pravičnom postupku. Izazovi pravosudnih transformacija na jugu 
Europe, Liber Amicorum Mihajlo Dika, Pravni fakultet Sveučilišta u Zagrebu, Zagreb, 2013., str. 219 - 243.

Visoki trgovački sud RH, Izvod iz zapisnika sa sastanka predsjednika trgovačkih sudova, Zagreb, Visoki trgovački sud RH, posl.br. Su-567/06, 19.10.2006., dostupno na: https://www.vtsrh.hr/uploads/Novosti/Dokumenti/5\%20preglednik\%20 mjera/3._Jedinstveni_plan_rjesavanja_svih_predmeta.doc

World Bank, Justice Sector Public Expenditure and Institutional Review, Resourcing the Justice Sector for Efficiency and Performance, Governance Global Practice Europe and Central Asia Region, World Bank, Washington, DC, 2014.

World Bank, National Development Strategy Croatia 2030 Policy Note: Justice Sector, World Bank, Washington, DC, 2019.

World Bank, Croatia-Justice Sector Support Project, Independent Evaluation Group, Project Performance Assessment Report 148794, World Bank, Washington, DC, 2020. 
Summary

\section{Marko Mećar*}

\section{AN ANALYSIS OF CERTAIN STATISTICAL INDICATORS REGARDING THE EFFICIENCY OF THE CROATIAN CIVIL JUDICIARY}

The intention of this paper is to provide an analysis of certain statistical indicators regarding the efficiency of the Croatian civil judiciary, since efficiency is one of the most important aspects of the judiciary. After a brief overview of different statistical indicators which may be used to measure the efficiency of the judiciary, this paper focuses on the analysis of the statistical indicators disposition time (hereinafter: DT) and clearance rate (hereinafter: CR), used by the European Commission for the Efficiency of Justice (hereinafter: CEPEJ) and the statistical indicators regarding the number of unresolved cases, the number of judges and the number of resolved cases per judge published by the ministry competent for the judiciary. Although CEPEJ's statistical indicators should be used cautiously due to methodological inconsistencies in the data, the paper concludes that these statistical indicators are useful to the extent that they can point to structural flaws in the judiciary system or can point to a trend of rise or decline in the judiciary's efficiency.

The central part of the paper focuses on the analysis of the DT and CR statistical indicators for the Croatian judiciary in general and compares it to the DT and CR statistical indicators for the judiciaries in other EU Member States. Further, the paper analyzes the statistical data published by the ministry competent for the judiciary regarding the number of unresolved cases, the number of judges and the number of resolved cases per judge, drawing conclusions therefrom on the efficiency of different parts of the Croatian judiciary. Also, historical statistical data published by the ministry competent for the judiciary are analyzed to show whether systematic problems in efficiency of concrete parts of the judiciary exist, as opposed to short-term efficiency shortfalls. The paper also highlights the lack of adequate, publicly available statistical data on the efficiency of the judiciary which limits the possibility of reaching a conclusion on the causes for such lower efficiency.

The paper concludes that, taking into consideration the publicly available data, it is possible to reach conclusions as to which parts of the judiciary have lower efficiency, those being litigation procedures, especially before first instance municipal courts. However,

\footnotetext{
Marko Mećar, mag. iur., LL. M., Attorney at Law, Laktić \& Partners Attorneys At Law, LLC, Selska cesta 90 a, 10000 Zagreb; marko.mecar@laktic.hr;

ORCID ID: orcid.org/0000-0003-2456-0865.

The views and opinions expressed in this article are those of the author and do not reflect the official policy or position of the law office.
} 
there are no publicly available data that would show the causes for the lower efficiency of these parts of the judiciary, even though public authorities have means at their disposal to obtain and publish such relevant data. Such practice by public authorities hinders further efforts of the interested public to focus the discussion on the real causes for the lower efficiency of the Croatian judiciary and ultimately, on the necessary reforms aimed at increasing its efficiency.

Keywords: judiciary, Republic of Croatia, efficiency analysis, CEPEJ, EU 